\title{
Estimated Withdrawals \\ from Principal Aquifers in the United States, 2000
}

By Molly A. Maupin and Nancy L. Barber

Circular 1279

U.S. Department of the Interior

U.S. Geological Survey 


\title{
U.S. Department of the Interior \\ Gale A. Norton, Secretary
}

\author{
U.S. Geological Survey \\ Charles G. Groat, Director
}

U.S. Geological Survey, Reston, Virginia: 2005

\author{
For sale by U.S. Geological Survey, Information Services \\ Box 25286, Denver Federal Center \\ Denver, CO 80225 \\ For more information about the USGS and its products: \\ Telephone: 1-888-ASK-USGS \\ World Wide Web: http://www.usgs.gov/
}

Any use of trade, product, or firm names in this publication is for descriptive purposes only and does not imply endorsement by the U.S. Government.

Although this report is in the public domain, permission must be secured from the individual copyright owners to reproduce any copyrighted materials contained within this report.

Suggested citation:

Maupin, M.A., and Barber, N.L., 2005, Estimated withdrawals from principal aquifers in the United States, 2000: U.S. Geological Survey Circular 1279, 46 p.

\section{Library of Congress Cataloging-in-Publication Data}

Maupin, Molly A.

Estimated withdrawals from principal aquifers in the United States, 2000 / by Molly A. Maupin, Nancy L. Barber.

p. cm. -- (U.S. Geological Survey circular ; 1279)

Includes bibliographical references.

ISBN 0-607-96780-3

1. Water withdrawals-United States. 2. Water consumption-United States. 3. Water-supply-United States. I. Barber, Nancy L. II. Title. III. Series.

TD493.M38 2005

333.91'0413'0973-dc22 


\section{CONTENTS}

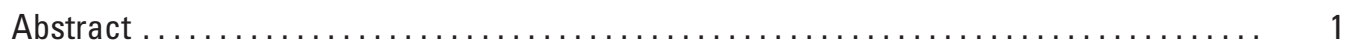

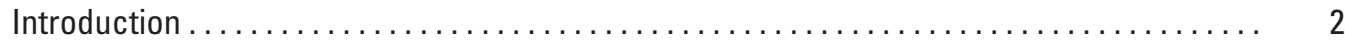

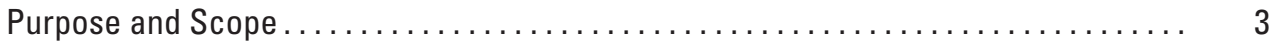

Sources of Data and Methods................................... 3

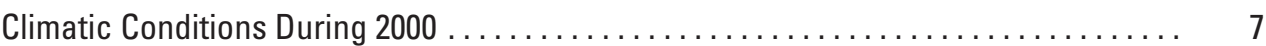

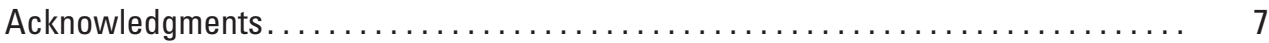

Aquifer terminology $\ldots \ldots \ldots \ldots \ldots \ldots \ldots \ldots \ldots \ldots \ldots \ldots \ldots \ldots \ldots \ldots \ldots \ldots \ldots \ldots \ldots,{ }_{8}$

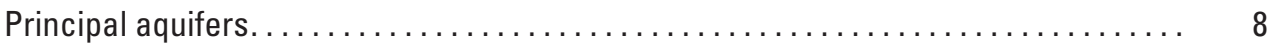

Major lithologic groups........................................ 9

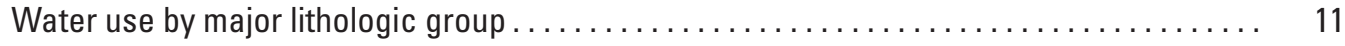

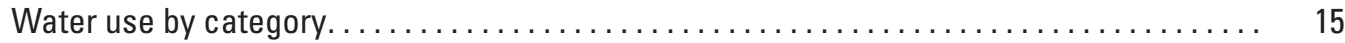

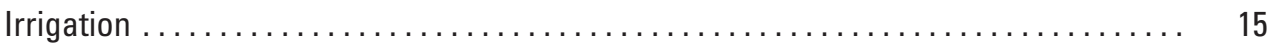

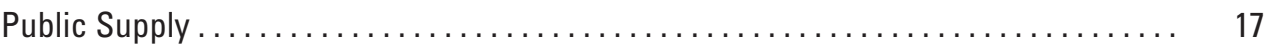

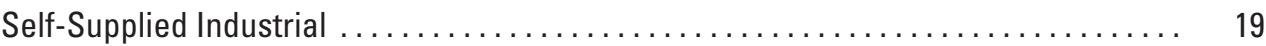

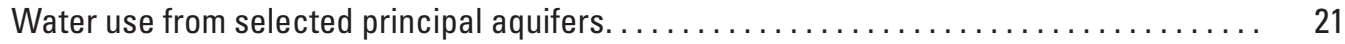

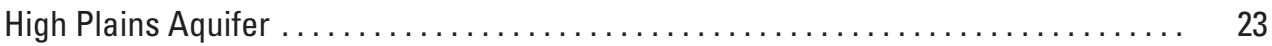

Central Valley Aquifer System. . . . . . . . . . . . . . . . . . . . . . . . . . . . . 24

Mississippi River Valley Alluvial Aquifer ........................... 25

Basin and Range Basin-Fill Aquifers . ............................. 26

Floridan Aquifer System ....................................... 27

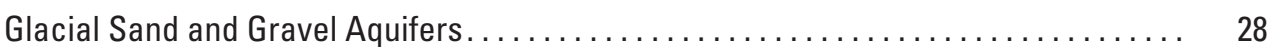

California Coastal Basin Aquifers .............................. 30

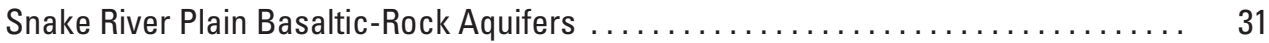

Coastal Lowlands Aquifer System ................................. 32

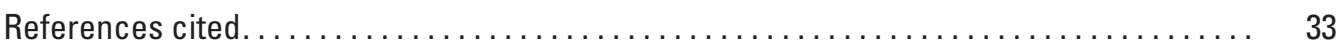




\section{FIGURES}

1. Principal aquifers of the United States $\ldots \ldots \ldots \ldots \ldots \ldots \ldots \ldots \ldots \ldots \ldots \ldots \ldots \ldots$

2. Examples of buried parts of principal aquifers of the United States. . . . . . . . . . 6

3. Total ground-water withdrawals, by water use, in the United States, 2000. . . . . . . 11

4. Total ground-water withdrawals, by lithologic group, in the United States, 2000 . . . . 11

5. Aquifers that provided most of the total withdrawals for irrigation, publicsupply, and self-supplied industrial water uses in the United States during 2000 . . . . 14

6. Total ground-water withdrawals for irrigation water use, by lithologic group,

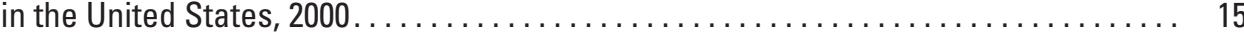

7. Total ground-water withdrawals for public-supply water use, by lithologic group, in the United States, 2000.

8. Total ground-water withdrawals for self-supplied industrial water use, by lithologic group, in the United States, 2000.

(1)




\section{Conversion Factors, Datum, and Abbreviated Water-Quality Unit}

\begin{tabular}{l|c|l}
\hline Multiply & By & To obtain \\
\hline foot $(\mathrm{ft})$ & 0.3048 & meter $(\mathrm{m})$ \\
mile $(\mathrm{mi})$ & 1.609 & kilometer $(\mathrm{km})$ \\
square mile $\left(\mathrm{mi}^{2}\right)$ & 2.590 & square kilometer $\left(\mathrm{km}^{2}\right)$ \\
acre-foot (acre-ft) & 1,233 & cubic meter $\left(\mathrm{m}^{3}\right)$ \\
million gallons per day $(\mathrm{Mgal} / \mathrm{d})$ & 1.121 & thousand acre-feet per year $(\mathrm{taf} / \mathrm{yr})$ \\
\hline
\end{tabular}

Horizontal coordinate information is referenced to the North American Datum of 1983 (NAD 83).

\section{Abbreviated water-quality unit:}

$\mathrm{mg} / \mathrm{L}$, milligrams per liter

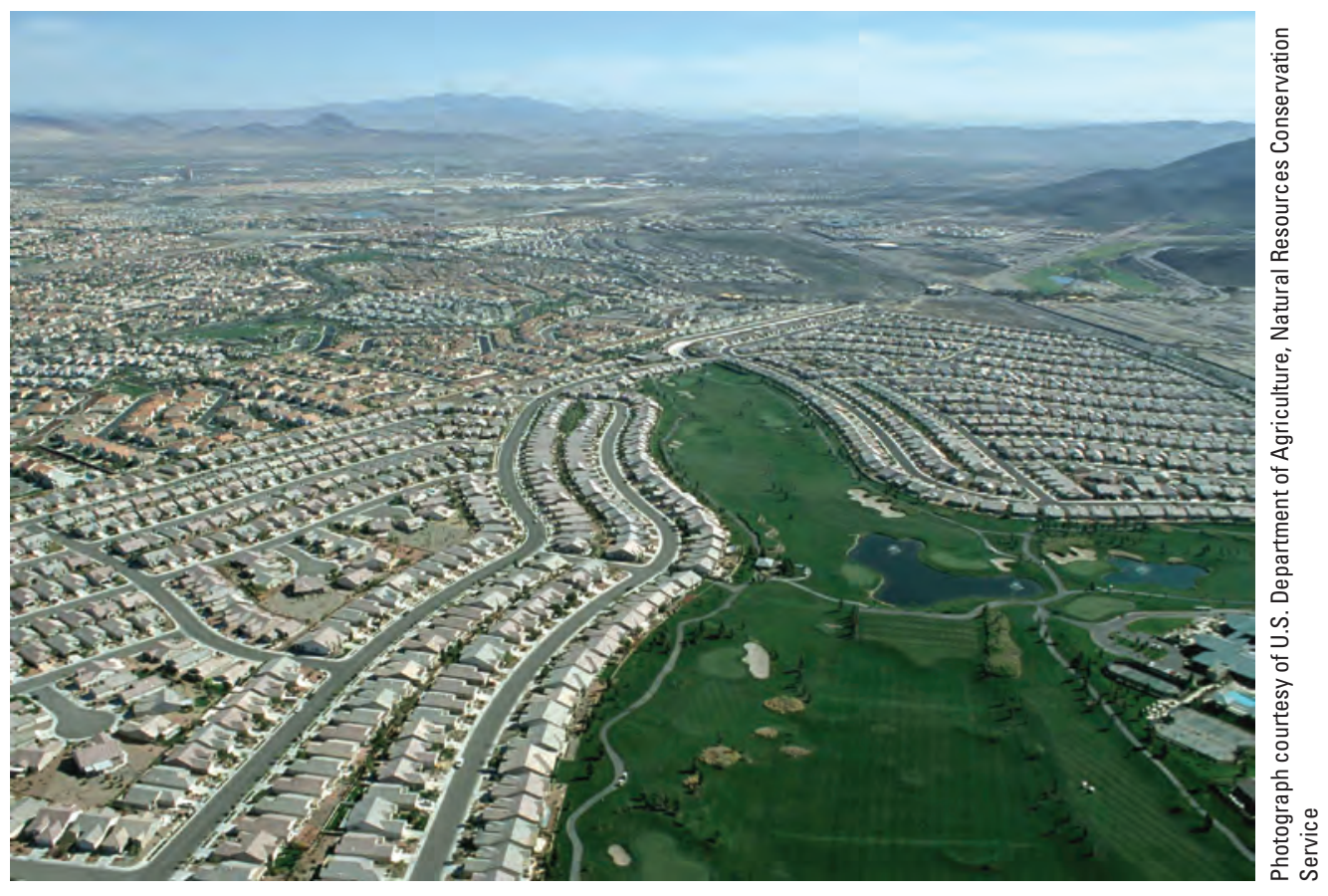




\title{
Estimated Withdrawals from Principal Aquifers in the United States, 2000
}

\author{
By Molly A. Maupin and Nancy L. Barber
}

\section{Abstract}

Fresh ground-water withdrawals from 66 principal aquifers in the United States were estimated for irrigation, public-supply, and self-supplied industrial water uses for the year 2000. Total ground-water withdrawals were 76,500 million gallons per day, or 85,800 thousand acre-feet per year for these three uses. Irrigation used the largest amount of ground water, 56,900 million gallons per day, followed by public supply with 16,000 million gallons per day, and self-supplied industrial with 3,570 million gallons per day. These three water uses represented 92 percent of the fresh groundwater withdrawals for all uses in the United States, the remaining 8 percent included self-supplied domestic, aquaculture, livestock, mining, and thermoelectric power uses.

Aquifer withdrawals were categorized by five lithologic groups: unconsolidated and semiconsolidated sand and gravel aquifers, carbonate-rock aquifers, igneous and metamorphic-rock aquifers, sandstone aquifers, and sandstone and carbonate-rock aquifers. Withdrawals from aquifers that were not included in one of the 66 principal aquifers were reported in an "Other" aquifers group. The largest withdrawals in the United States were from unconsolidated and semiconsolidated sand and gravel aquifers, which accounted for 80 percent of total withdrawals from all aquifers. Carbonaterock aquifers provided 8 percent of the withdrawals, and igneous and metamorphic-rock aquifers, 6 percent. Withdrawals from sandstone aquifers, from sandstone and carbonate-rock aquifers, and from the "Other" aquifers category each constituted about 2 percent of the total withdrawals reported.

Fifty-five percent of the total withdrawals for irrigation, public-supply, and self-supplied industrial water uses were provided by the High Plains aquifer, California Central Valley aquifer system, the Mississippi River Valley alluvial aquifer, and the Basin and Range basin-fill aquifers. These aquifers provided most of the withdrawals for irrigation. The High Plains aquifer was the most intensively used aquifer in the United States. This aquifer provided 23 percent of the total withdrawals from all aquifers for irrigation, public-supply, and self-supplied industrial water uses combined, and 30 percent of the total withdrawals from all aquifers for irrigation.

The primary aquifers used for public supply were the glacial sand and gravel aquifers of the Northeastern and North-Central States, the California Coastal Basin aquifers, the Floridan aquifer system, the Basin and Range basin-fill aquifers, and the Coastal lowlands aquifer system along the Gulf Coast. These five aquifers provided 43 percent of the total withdrawals from all aquifers for public supply. The glacial sand and gravel aquifers, Coastal lowlands aquifer system, Floridan aquifer system, and Cambrian-Ordovician aquifer system were the primary sources of water for self-supplied industrial use; these aquifers provided 46 percent of the total ground-water withdrawals for that use.

\section{How much water is one million gallons per day?}

One million gallons per day is a rate of flow

for water. One million gallons, as a volume

of water, is enough to cover 1 acre of land

with about 3 feet of water, or fill nearly four

Olympic-sized swimming pools. Over the

course of a year, one million gallons per day

is enough water to cover 1 acre of land to a

depth of 1,121 feet, or fill 1,442 Olympic-

sized swimming pools. 


\section{INTRODUCTION}

The U.S. Geological Survey (USGS) has compiled and reported data about the volumes of water used in homes, businesses, industries, and on farms within the United States since 1950. These data are compiled in 5-year increments and, when combined with other USGS water data, provide opportunities to study the effects of human activities on the Nation's water resources, observe trends in water use, and address emerging issues such as water availability, especially in areas of the Nation where water is scarce.

This report contains a compilation of fresh groundwater withdrawal data for the year 2000 for irrigation, public-supply and self-supplied industrial water uses from principal aquifers within the United States, Puerto Rico, and the U.S. Virgin Islands. The term withdrawal describes how much water is pumped or otherwise removed from an aquifer; the term water use describes the manner in which the water is used, such as irrigation.

Data for this report were collected concurrently with the data that are presented in the report "Estimated Use of Water in the United States in 2000" (Hutson and others, 2004). The USGS, in cooperation with State and local agencies, compiled water-use estimates for 2000 for each county in the United States, the District of Columbia, Puerto Rico, and the U.S. Virgin Islands, and for the principal aquifers in each State. County and aquifer water-use estimates and ancillary data were entered into a database (the Aggregate Water-Use

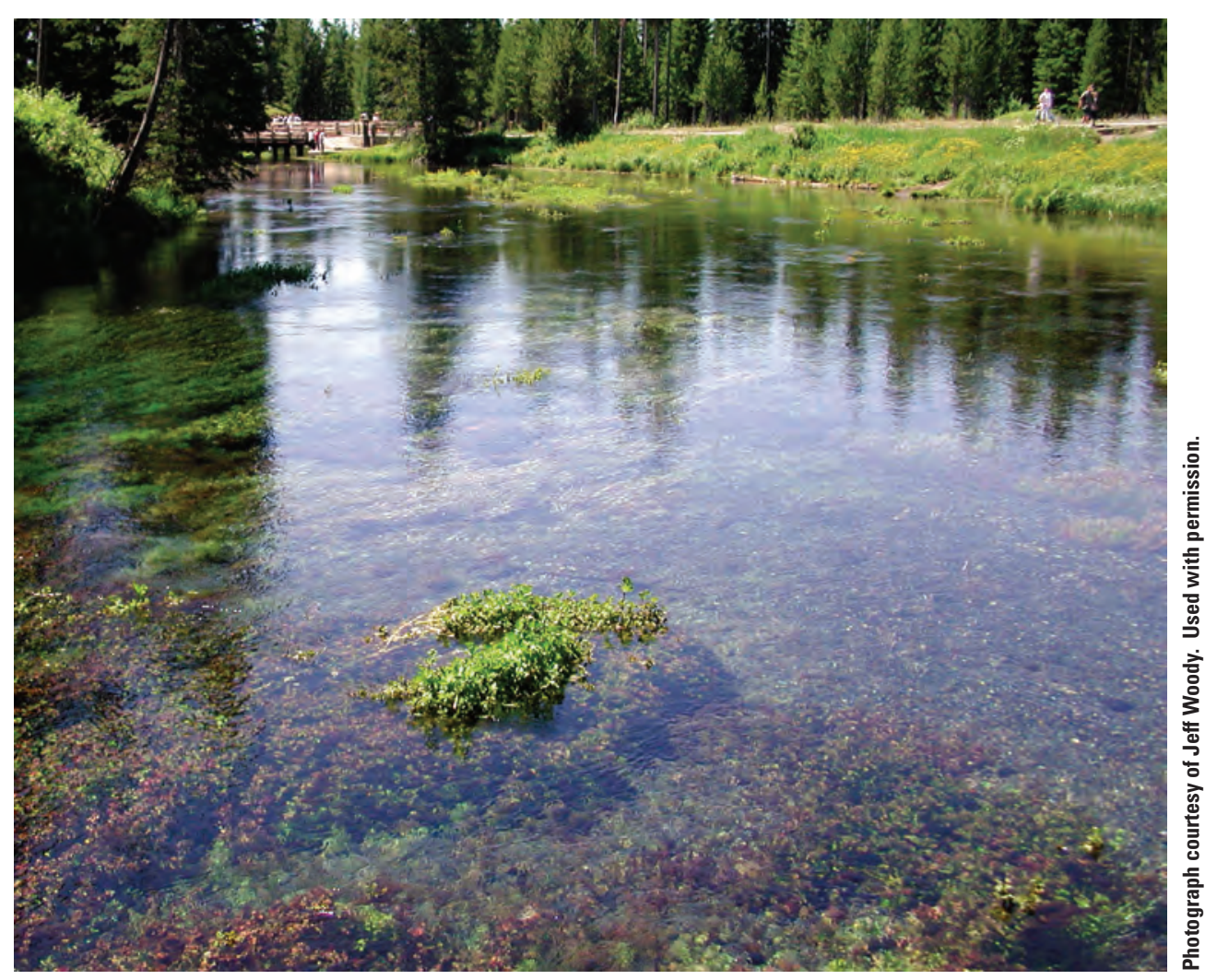

Data System) in each USGS State office and were reviewed by the USGS and cooperating agencies. Each USGS study chief compiled and analyzed information from various sources, made estimates of missing data, and prepared documentation that identified the sources of water-use information and methods used to determine water use for their State. Each USGS study chief was responsible for determining the most reliable sources of information available for estimating water use for their State.

Total ground-water withdrawals for all uses in the United States, estimated by county and reported by Hutson and others (2004), included irrigation, public-supply, and selfsupplied industrial, as well as self-supplied domestic, aquaculture, livestock, mining, and thermoelectric power uses. Total fresh ground-water withdrawals for all uses in the United States were 83,300 Mgal/d, and saline ground-water withdrawals during 2000 were $1,260 \mathrm{Mgal} / \mathrm{d}$, or 1.5 percent of the total fresh and saline ground-water withdrawals of $84,500 \mathrm{Mgal} / \mathrm{d}$. Ground water accounted for 21 percent of the total water use from all sources.

Fresh ground-water withdrawals by aquifer were estimated only for irrigation, public-supply, and self-supplied industrial water uses for each State. Saline ground-water withdrawals were estimated for self-supplied industrial use by county but not by aquifer and, thus, are not included in this report. Only fresh ground-water withdrawals were estimated for public-supply and irrigation use for both counties and aquifers. These estimates may include water that exceeds the common threshold of $1,000 \mathrm{mg} / \mathrm{L}$ for fresh-water. For the remainder of this report, the term total withdrawals means total withdrawals for irrigation, public-supply, and selfsupplied industrial uses only (unless otherwise specified). Total withdrawals by aquifer, and by aquifer and State, are described in table 1 and table 2 (back of report), respectively. Additional information about groundwater withdrawals by aquifer is available upon inquiry to the USGS water-use project chiefs, listed for each State at http://water.usgs.gov/watuse/

Big Springs, Idaho 


\section{Purpose and Scope}

This report summarizes estimates of fresh ground-water withdrawals for irrigation, public-supply, and self-supplied industrial uses from principal aquifers in the United States during the year 2000. Data were collected for 66 aquifers, most of which are illustrated on the USGS principal aquifer map of the National Atlas of the United States (U.S. Geological Survey, 2003) and shown in figure 1 and figure 2. The map is accessible on the web at http://nationalatlas.gov/mld/aquifrp.html This report is organized into four main sections. The first section describes aquifer terminology; the second section summarizes total aquifer withdrawals by major lithologic group; the third section summarizes withdrawals for each of the reported water-use categories (irrigation, public supply, and self-supplied industrial), specifying the aquifers and States that constitute most of the withdrawals for each type of use; the fourth section discusses withdrawals from the nine principal aquifers that account for most of the ground-water withdrawals in the United States.

\section{Sources of Data and Methods}

The general approach for estimating aquifer withdrawals was first to estimate total ground-water withdrawals for each category of water use at the county level, as were reported by Hutson and others (2004). Additional information on the methods used to estimate total ground-water withdrawal by category can be found in a report by Kenny (2004). Withdrawals may have been derived using site-specific information or estimated using coefficients and ancillary data. The next step was to allocate the county withdrawals to the principal aquifers in each State. In some parts of the United States, only one aquifer is present in a given county, and the allocation of a county withdrawal amount is simple. In other parts of the United States, multiple aquifers are present and may be stacked. This situation requires information on the exact location of the water withdrawals, the aquifer extent, well depths, and other information to determine how to allocate the withdrawal to the aquifers. Some individual wells withdraw water from more than one aquifer, and estimating the contribution of each aquifer was problematic. In other cases, information on well depth was not available and, therefore, the source aquifer was unknown. In cases where site-specific information was not available, the best judgment of the USGS study chief in that State was used to allocate the withdrawals to the appropriate aquifers and integrate available ancillary data on aquifer properties. Ancillary data included information such as full extent of aquifer, productivity, depth to water, and suitability of water quality for the particular water use. Local experts also were consulted about aquifer availability and use, and the approach used may have varied because of the availability of different information in each State. Staff in each State reviewed aquifer withdrawal estimates for completeness and accuracy prior to final approval. Withdrawals by category may not agree with those reported by Hutson and others because of rounding.

If a principal aquifer underlies more than one State and only one State reported withdrawals for that aquifer, the withdrawals are listed in table 2 only for the reporting State. If a principal aquifer underlies only one State and no withdrawals were reported, the aquifer is still listed in table 2 for that State, but the withdrawals are reported as zero (the Southern Nevada volcanic-rock aquifer, which is present only in Nevada, was the only such aquifer). 


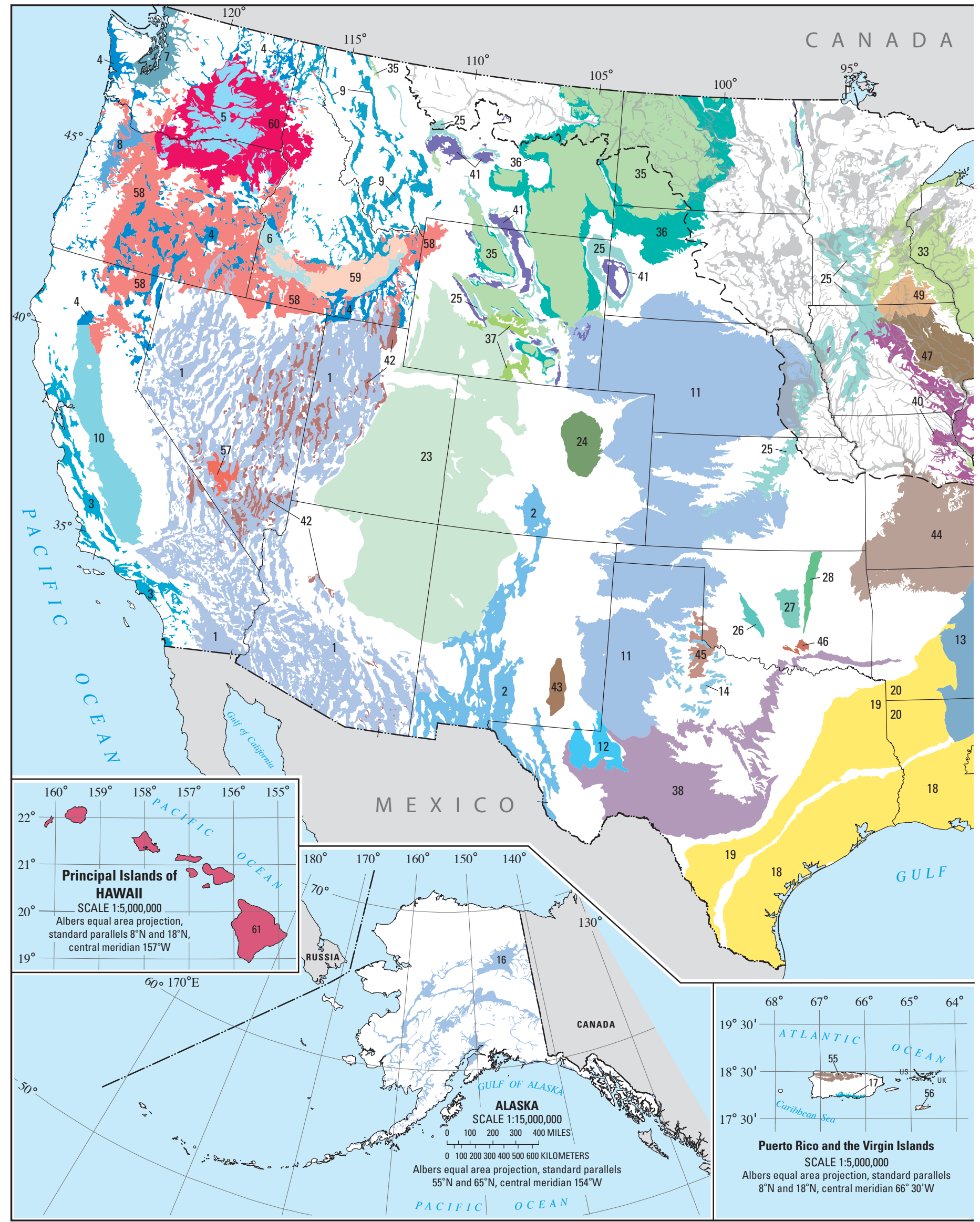

Figure 1. Principal Aquifers of the United States (Modified from Principal Aquifers, 1:5,000,000, The National Atlas of the United States 


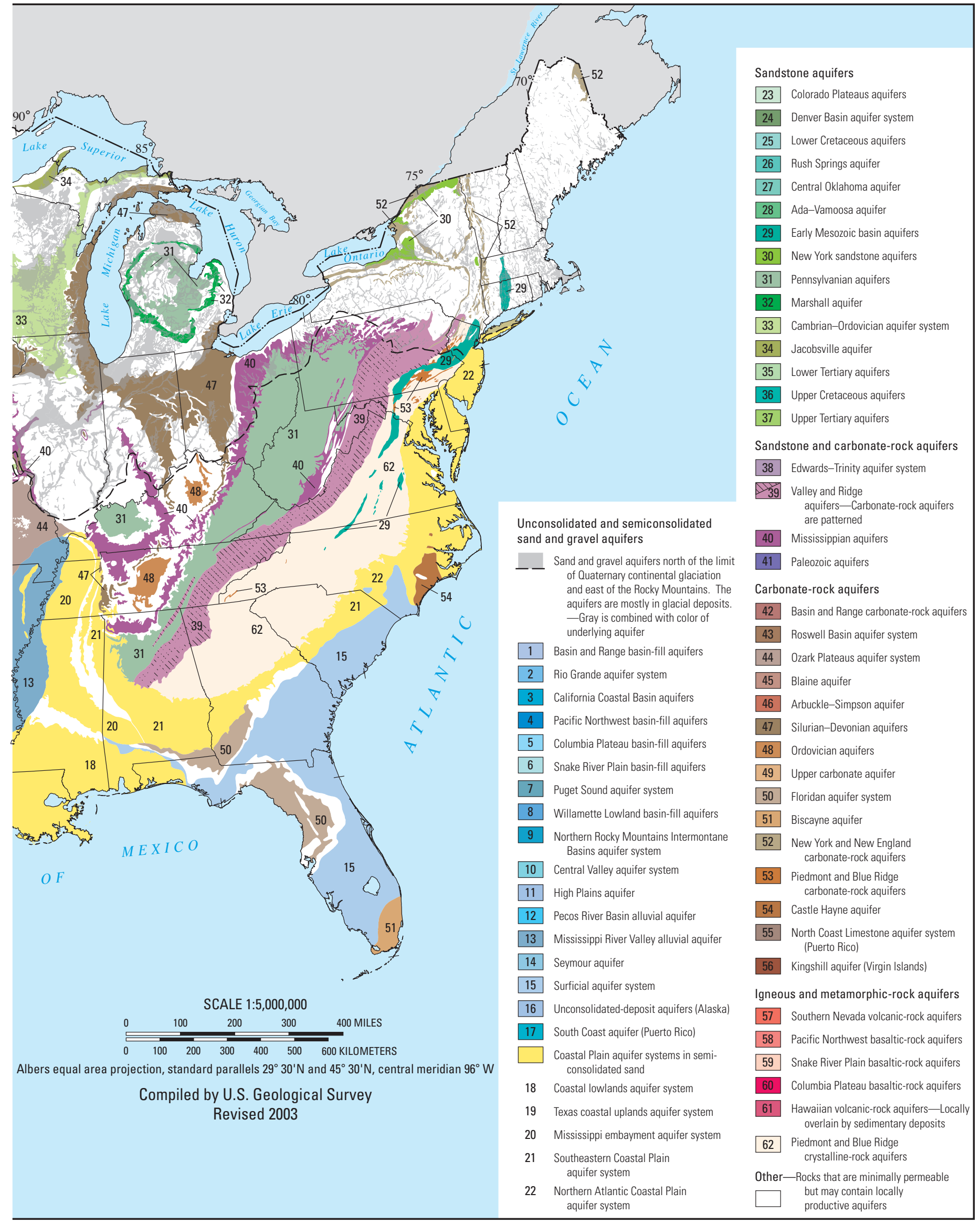

America, U.S. Geological Survey, 2003) 


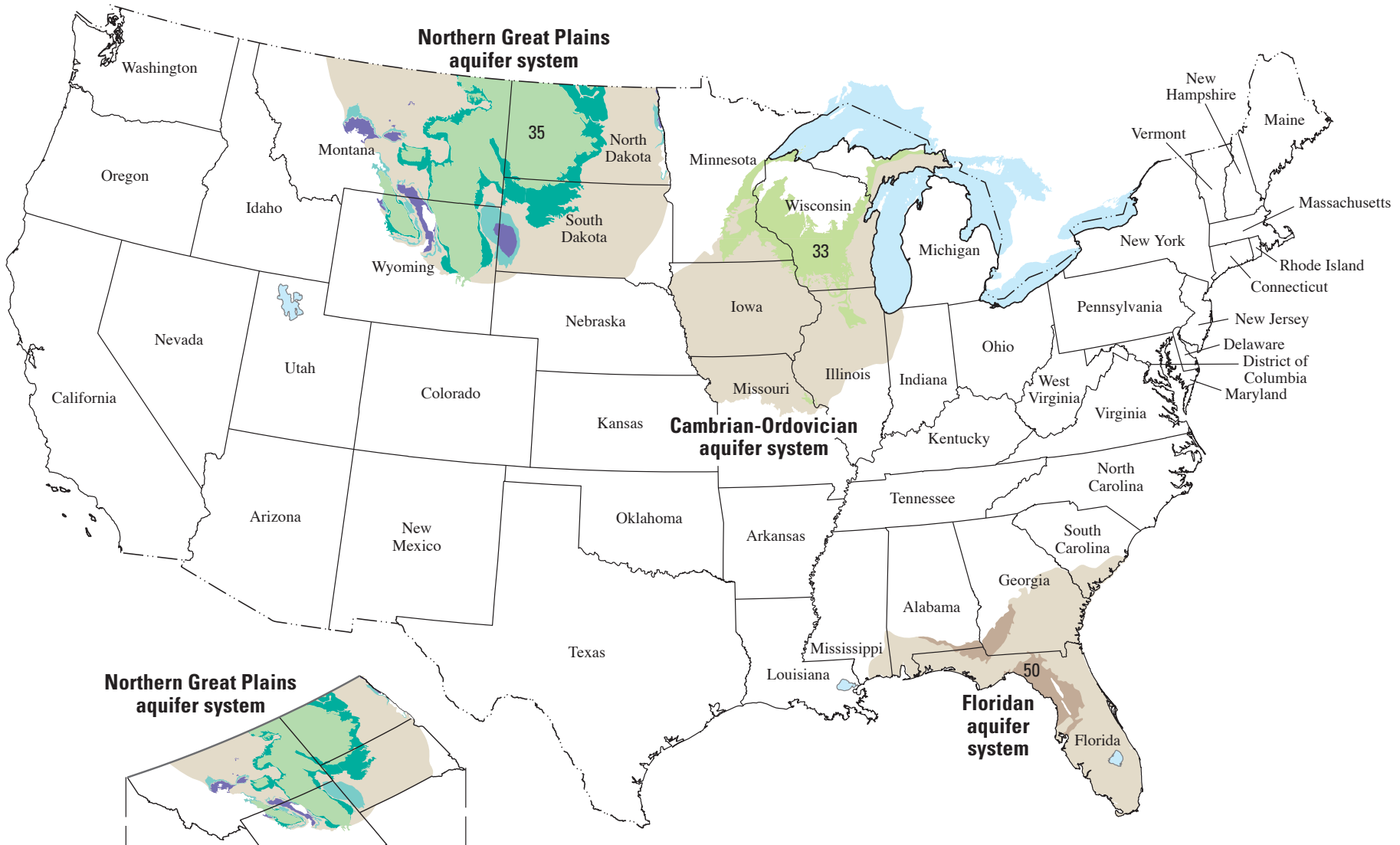

Source: Miller, James A., ed., 2000,

Ground Water Atlas of the United

States: U.S. Geological Survey, 404 p.

Sandstone aquifers

25 Lower Cretaceous aquifers

33 Cambrian-Ordovician aquifer system

35 Lower Tertiary aquifers

36 Upper Cretaceous aquifers

Sandstone and carbonate-rock aquifers

41 Paleozoic aquifers

Carbonate-rock aquifers

50 Floridan aquifer system

Buried portion of aquifer system

Figure 2. Examples of buried parts of principal aquifers in the United States. (Modified from Principal Aquifers 1:5,000,000; U.S. Geological Survey, 2003) 


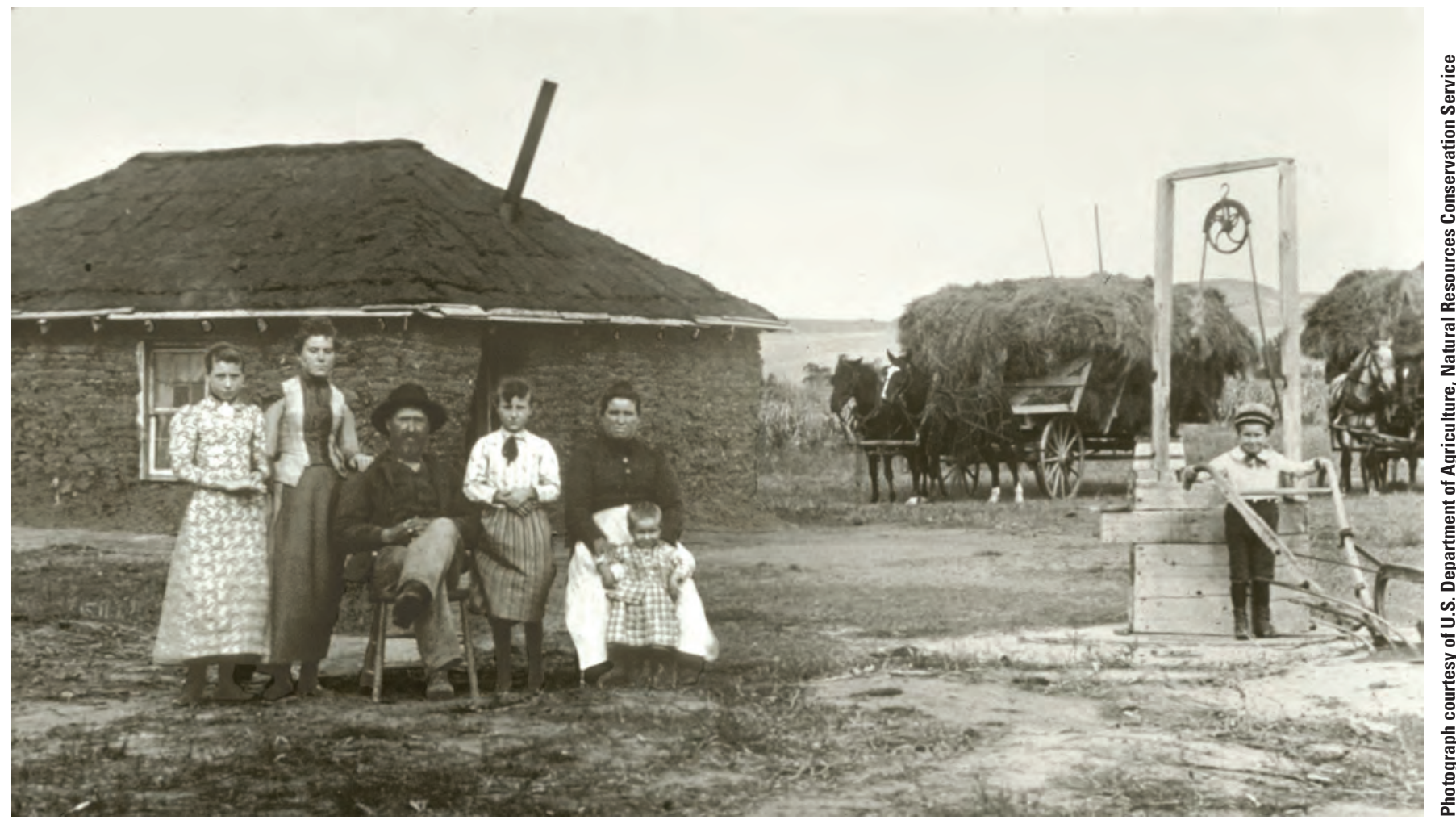

\section{Climatic Conditions During 2000}

Climatic conditions affect both water resources (such as aquifers) and water withdrawals. Precipitation, in the form of rain and snow, recharges aquifers either by direct percolation down to the aquifers or by leakage from streams, rivers, lakes, and wetlands. When the climate is drier than normal, recharge is diminished and water use increases, primarily as a result of additional irrigation needs for crops and lawns. The opposing conditions of diminished recharge and increased withdrawals stress aquifer systems, especially in areas where ground water is not recharged at a sufficient rate to sustain water levels in the aquifer.

Precipitation was below normal during 2000 in many areas of the Nation, although two northern States were unusually wet. Florida experienced the driest year on record, and precipitation in Alabama and Georgia was far below normal. Precipitation in the Pacific Northwest also was below normal. In contrast, New York and North Dakota experienced record wet years, and the Great Lakes region was just slightly wetter than normal.

The 2000 drought, measured using the Palmer Drought Index (National Oceanic and Atmospheric Administration, 2001), peaked at 36 percent of the contiguous United States in August but decreased in November to about 6 percent, owing to heavy rains late in the year in many of the droughtstricken areas. Summer to early autumn (July to September) was the driest such period in 106 years for the United States. The drought was most severe in the southern States of Alabama, Florida, Georgia, Louisiana, Mississippi, and South Carolina. Much of the West was in a severe drought, including most of Arizona, Idaho, Montana, New Mexico, Utah, and Wyoming, southern California and northern Nevada, and eastern Oregon and Washington. Extremely dry areas included the States of Arkansas, Kansas, Nebraska, and most of Texas. The dry conditions for much of the United States in 2000 suggest that ground-water withdrawals may have been greater overall than would have occurred in an average year.

\section{Acknowledgments}

The authors gratefully acknowledge the USGS study chiefs in each State who compiled the data for this report and the many State and local agencies that shared data and expertise with the USGS. Additional thanks are extended to the USGS Regional Water-Use Specialists for their contributions and to Kristin Linsey for her efforts in verifying the data and tables. 
An aquifer is defined as

a geologic formation, group of formations, or

part of a formation that

contains sufficient satu-

rated permeable mate-

rial to yield significant

quantities of water to

wells and springs.

\section{AQUIFER TERMINOLOGY}

Ground water occurs in permeable rocks and sediments called aquifers. An aquifer is defined as a geologic formation, group of formations, or part of a formation that contains sufficient saturated permeable material to yield significant quantities of water to wells and springs (U.S. Geological Survey, 1999). The permeability of aquifers, or the ease with which water can move through the aquifer material, varies widely depending on the type of materials that constitute the aquifer. Fine-grained material such as clay or silt is less permeable than sand and gravel. Crystalline rocks such as granite have a very low permeability unless the rocks have been fractured, which creates openings through which ground water can move or be stored. More permeable aquifers can yield more water to wells. However, less permeable aquifers that are very thick can be as productive as very permeable but thinner aquifers.

Aquifers are categorized as either confined or unconfined. In a confined aquifer, the ground water is in a geologic unit that is overlain by less permeable layers, and the water level in a well that is drilled into a confined aquifer is higher than the top of the aquifer. In some cases, the water level may even be high enough to flow at land surface. In an unconfined or water-table aquifer, the water level is free to rise and fall within the aquifer materials. The water level in a well that is drilled into an unconfined aquifer is generally at the level of the water table.

Aquifers may be combined into aquifer systems, or groups of aquifers, either because the aquifers are hydraulically connected or because they have common geologic and hydrologic characteristics (U.S. Geological Survey, 2003). For simplicity of presentation in this report, aquifers and aquifer systems collectively are referred to as aquifers, though the proper terminology is used for specific aquifer and aquifer system names.

\section{Principal Aquifers}

A principal aquifer, as used in this report and in the principal aquifer map of the National Atlas of the United States (U.S. Geological Survey, 2003), is defined as a regionally extensive aquifer or aquifer system that has the potential to be used as a source of potable water. The aquifers and aquifer systems discussed in this report (figure 1, figure 2) are those defined in the National Atlas, with the addition of the following: the intermediate aquifer system located in Florida, described in the Ground-Water Atlas of the United States, Segment 6 (Miller, 1990, p. 11); the New England crystalline-rock aquifers, which are described as 
crystalline-rock aquifers in the Ground-Water Atlas of the United States, Segment 12 (Olcott, 1995); the Northern Great Plains aquifer system, which includes three sandstone aquifers from the principal aquifers map (Lower Tertiary aquifers, Upper Cretaceous aquifers, and the Lower Cretaceous aquifers in Montana, North Dakota, South Dakota, and Wyoming) and possibly Paleozoic aquifers when they cannot be separated; and alluvial aquifers, which include alluvial materials such as stream-valley aquifers not included in another named principal aquifer (Roy Sonenshein, U.S. Geological Survey, written commun., 2004).

The principal aquifer list is not all inclusive; aquifers were selected to represent those with known areal extent, high productivity or use, and national significance. Withdrawals that could not be allocated to one of the 66 principal aquifers were included under "Other" aquifers. These withdrawals might be from formations that are not definitively correlated with one of the principal aquifers.

In many parts of the United States, principal aquifers underlie other aquifers, including other principal aquifers. This situation often is referred to as stacked aquifers. Shallow aquifers generally are developed first, if the water quality and productivity are sufficient to meet the needs of the intended uses. As ground-water development continues, aquifers that are deeper also might be developed.

Maps such as the National Atlas principal aquifer map cannot display the full extent of the aquifers where they are covered by other units, so the aquifer may extend over a much larger area than is shown. As examples, the full extent of the Cambrian-Ordovician aquifer system, the Floridan aquifer system, and the Northern Great Plains aquifer systems, including where they are buried beneath other aquifers, is illustrated in figure 2 .

\section{Major Lithologic Groups}

Each principal aquifer is classified into one of five lithologic types:

- unconsolidated and semiconsolidated sand and gravel,

- carbonate rock,

- igneous and metamorphic rocks,

- sandstone rock, and

- sandstone and carbonate rocks
However, additional lithologies may be present in principal aquifers that are listed as one type of lithology. For example, a sand and gravel unit may be present in an aquifer that is predominantly igneous.

Unconsolidated and semiconsolidated sand and gravel aquifers consist of gravel, sand, silt, and clay, possibly interbedded with some carbonate rocks. Unconsolidated sand and gravel aquifers are of four types: basin-fill aquifers, blanket sand and gravel aquifers, glacial-deposit aquifers, and alluvial aquifers (U.S. Geological Survey, 2003). Water in these aquifers generally is under unconfined conditions. Basin-fill aquifers consist of sediments that fill depressions formed by faulting or erosion. Blanket aquifers are broad, sheetlike sediments that have been deposited by rivers, by wind, or in beach or shallow marine environments. Glacial deposits also are found in broad areas but were deposited by glaciers or by glacial meltwater. Alluvial aquifers are present in and near major streams and consist of sediments deposited by rivers or streams. These types of aquifers are not identified on the principal aquifer map (figure 1), because they were too small to map accurately at that scale. In this report, the alluvial aquifer category only includes stream-valley aquifers that have not been accounted for as part of other principal aquifers. Semiconsolidated sand aquifers underlie the Coastal Plains bordering the Atlantic Ocean and the Gulf of Mexico and generally form a wedge of sediment that thickens toward the sea. Most of the water in semiconsolidated sand aquifers is under confined conditions.

Sandstone aquifers generally are more geographically extensive than any other type of consolidated rocks and consist of consolidated sandstone where water is stored both in the pores between sand grains and in secondary openings such as fractures. Water in sandstone aquifers may exist under confined and unconfined conditions.

Sandstone and carbonate-rock aquifers are present mostly in the eastern half of the Nation, but also occur in Texas and in Oklahoma, Arkansas, Montana, Wyoming, and South Dakota. They consist of interbedded sandstone and carbonate rocks. The carbonate rocks generally yield more ground water than do the sandstone rocks, owing to dissolution and larger open-pore space. Water in aquifers of this type may exist under confined and unconfined conditions.

Carbonate-rock aquifers generally consist of limestone, though dolomite and marble aquifers exist. Carbonate materials were deposited in marine environments, and most carbonate-rock aquifers are found in the central and southeastern parts of the United States. Some carbonate-rock aquifers store water in intergranular pore spaces, but most limestones have secondary pore space, formed by dissolution 
of the rock after it was deposited, and also may have fractures that store and transmit water. Water in carbonate-rock aquifers may exist under confined and unconfined conditions.

Igneous and metamorphic-rock aquifers are of two general types, basaltic and other volcanic-rock aquifers, and crystallinerock aquifers. Basaltic and other volcanic-rock aquifers have a wide range of hydraulic properties, depending upon the rock type and process of deposition. The most productive basaltic aquifers are those that have interflow zones - very permeable zones at the top of one flow and the bottom of the overlying flow. Water in crystalline-rock aquifers is present in fractures in the rock and in the weathered material that overlies the rock.

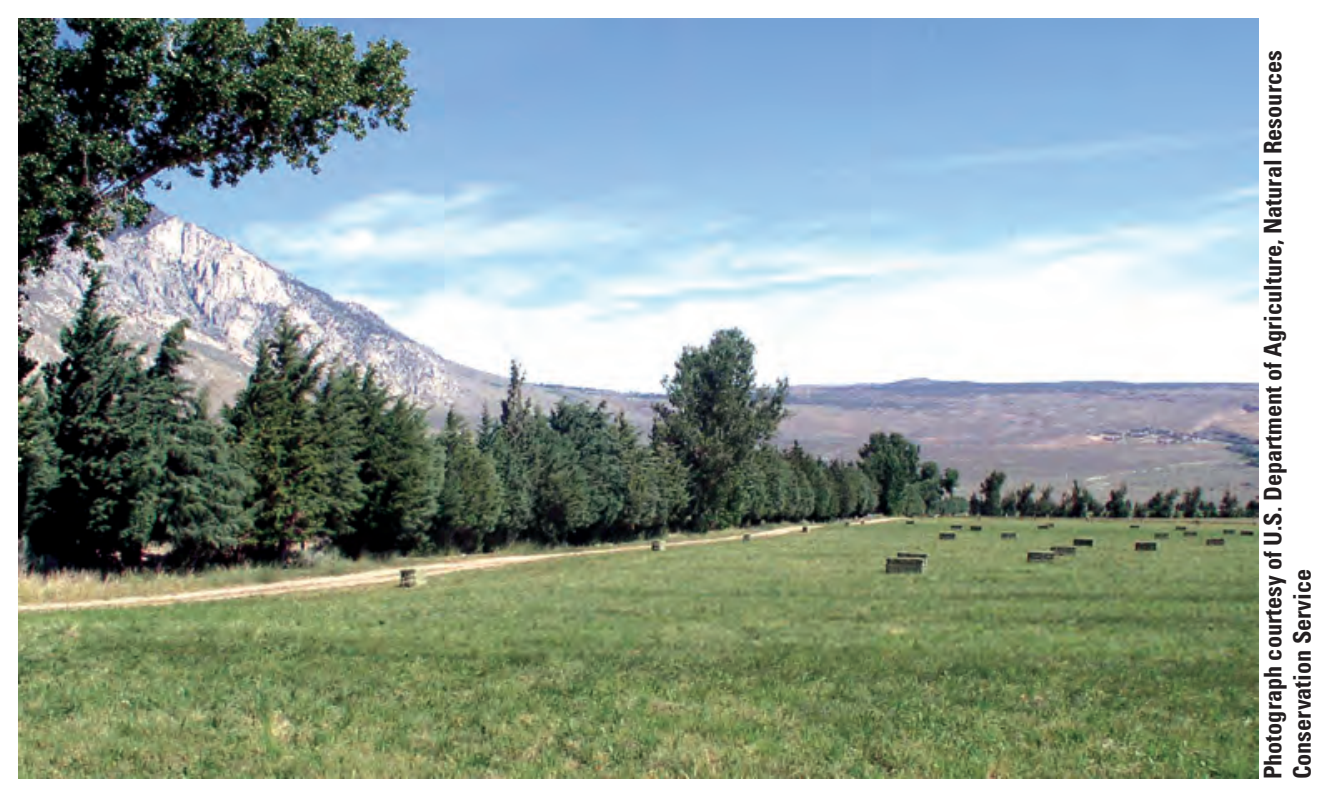




\section{WATER USE BY MAJOR LITHOLOGIC GROUP}

Fresh ground-water withdrawals for irrigation, public-supply and self-supplied industrial uses totaled $76,500 \mathrm{Mgal} / \mathrm{d}$, or about 92 percent of the total fresh ground-water withdrawals for all water uses reported by Hutson and others (2004), which also included selfsupplied domestic, aquaculture, livestock, mining, and thermoelectric power uses. Of this total, 56,900 Mgal/d (74 percent) was for irrigation, $16,000 \mathrm{Mgal} / \mathrm{d}$ (21 percent) was for public supply, and 3,570 Mgal/d (5 percent) was for self-supplied industrial uses (figure 3 ). Total ground-water withdrawals by lithologic group are shown in figure 4, and total ground-water withdrawals by aquifer, for irrigation, public-supply, and self-supplied industrial water uses are listed in table 1. Aquifers that provided most (90 percent) of the total withdrawals for irrigation, public-supply, and self-supplied industrial water uses in the United States are shown in figure 5.

Most ground water was withdrawn from aquifers that consisted of unconsolidated and semiconsolidated sand and gravel; this lithology accounted for $61,400 \mathrm{Mgal} / \mathrm{d}$, or 80 percent of total withdrawals from all aquifers (figure 4 and table 1). Most of the withdrawals from this lithology were from the High Plains aquifer, Central Valley aquifer system, Mississippi River Valley alluvial aquifer, and Basin and Range basin-fill aquifers, and about 94 percent of the water from these aquifers was used for irrigation. They also provided 55 percent of the total withdrawals from all aquifers for irrigation, public-supply, and self-supplied industri-

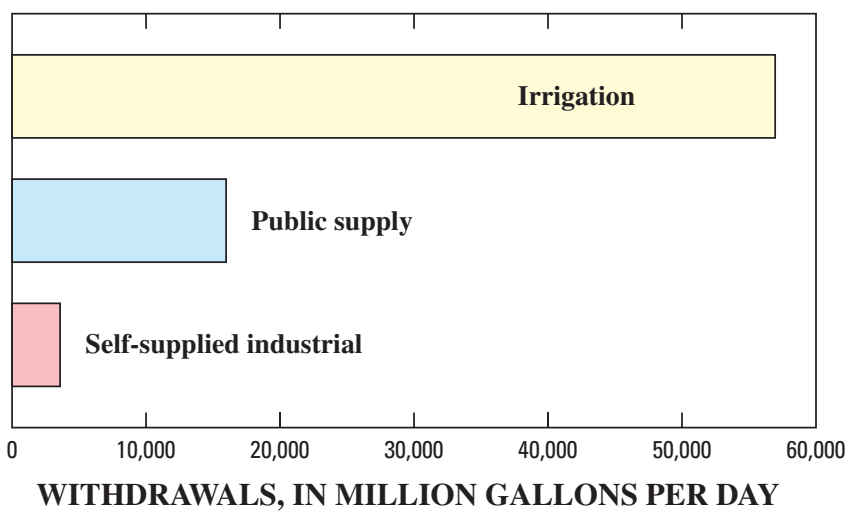

Figure 3. Total ground-water withdrawals, by water use, in the United States, 2000

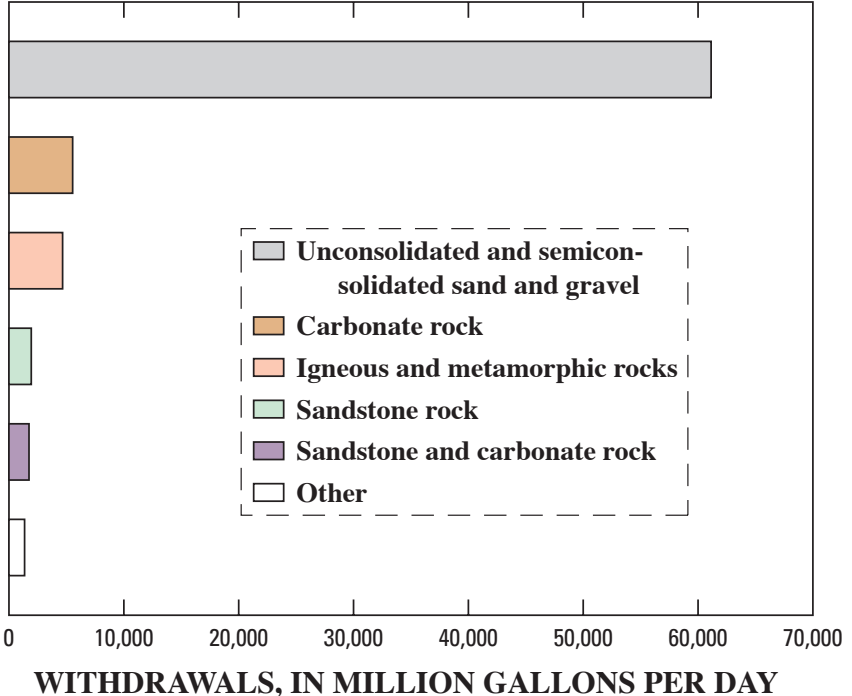

Figure 4. Total ground-water withdrawals, by lithologic group, in the United States, 2000

al water uses. The sand and gravel aquifers north of the limit of Quaternary continental glaciation and east of the Rocky Mountains (hereafter referred to as the "glacial sand and gravel aquifers") also are included in this lithology; slightly more public-supply withdrawals than irrigation withdrawals were reported for the sand and gravel aquifers. Combined, the five aquifers listed here provided 75 percent of total withdrawals from all of the aquifers in the unconsolidated and semiconsolidated sand and gravel lithology.

Carbonate-rock aquifers provided 8 percent of total withdrawals from all aquifers. The largest withdrawals in this lithology were from the Floridan aquifer system, which accounted for 62 percent of total carbonate-rock aquifer withdrawals. The Floridan aquifer system was used primarily for irrigation and public supply.

Igneous and metamorphic-rock aquifers provided 6 percent of total withdrawals from all aquifers. The largest withdrawals in this lithology were from the Snake River Plain basaltic-rock aquifer, which accounted for 56 percent of the total withdrawals from this lithology. Most of the water from this aquifer system was used for irrigation.

Sandstone aquifers provided about 2 percent of total withdrawals from all aquifers; 45 percent of the total with- 
Table 1. Total ground-water withdrawals, by aquifer, for irrigation, public-supply, and self-supplied industrial water uses in the United States, 2000

[Total values have been rounded: No., aquifer number as shown in figure 1 explanation; bold denotes total withdrawals by major lithologic group and category; *, not shown in figure 1 explanation.]

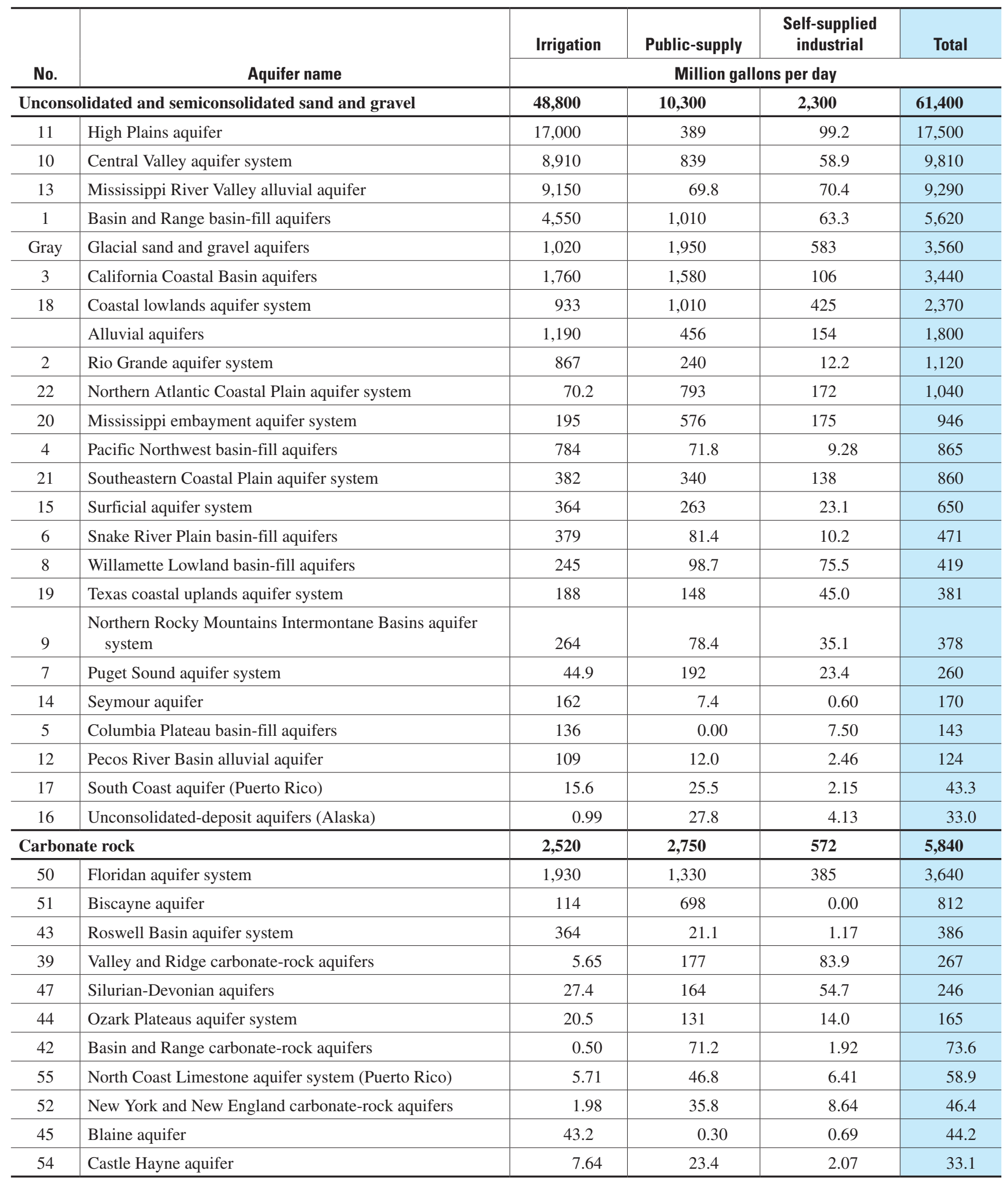


Table 1. Total ground-water withdrawals, by aquifer, for irrigation, public-supply, and self-supplied industrial water uses in the United States, , 2000-Continued

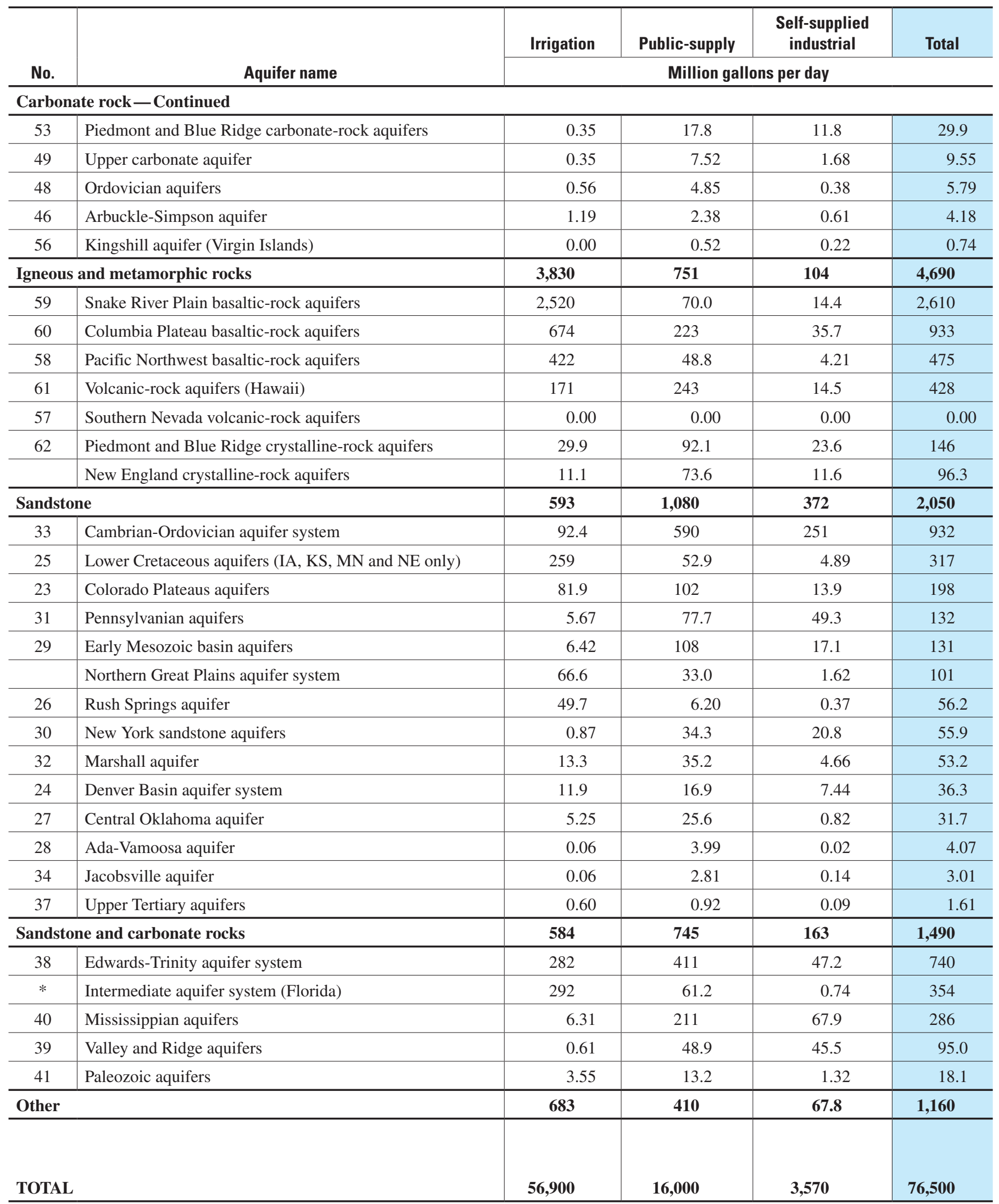


drawals from all sandstone aquifers were from the Cambrian-Ordovician aquifer system. More than half of the withdrawals from sandstone aquifers were used for public supply.

Sandstone and carbonate-rock aquifers provided about another 2 percent of total withdrawals from all aquifers; 73 percent of the total withdrawals from aquifers in this lithology were from the Edwards-Trinity and the intermediate aquifer system (Florida). Half of the total withdrawals from all sandstone and carbonate-rock aquifers were used for public supply.

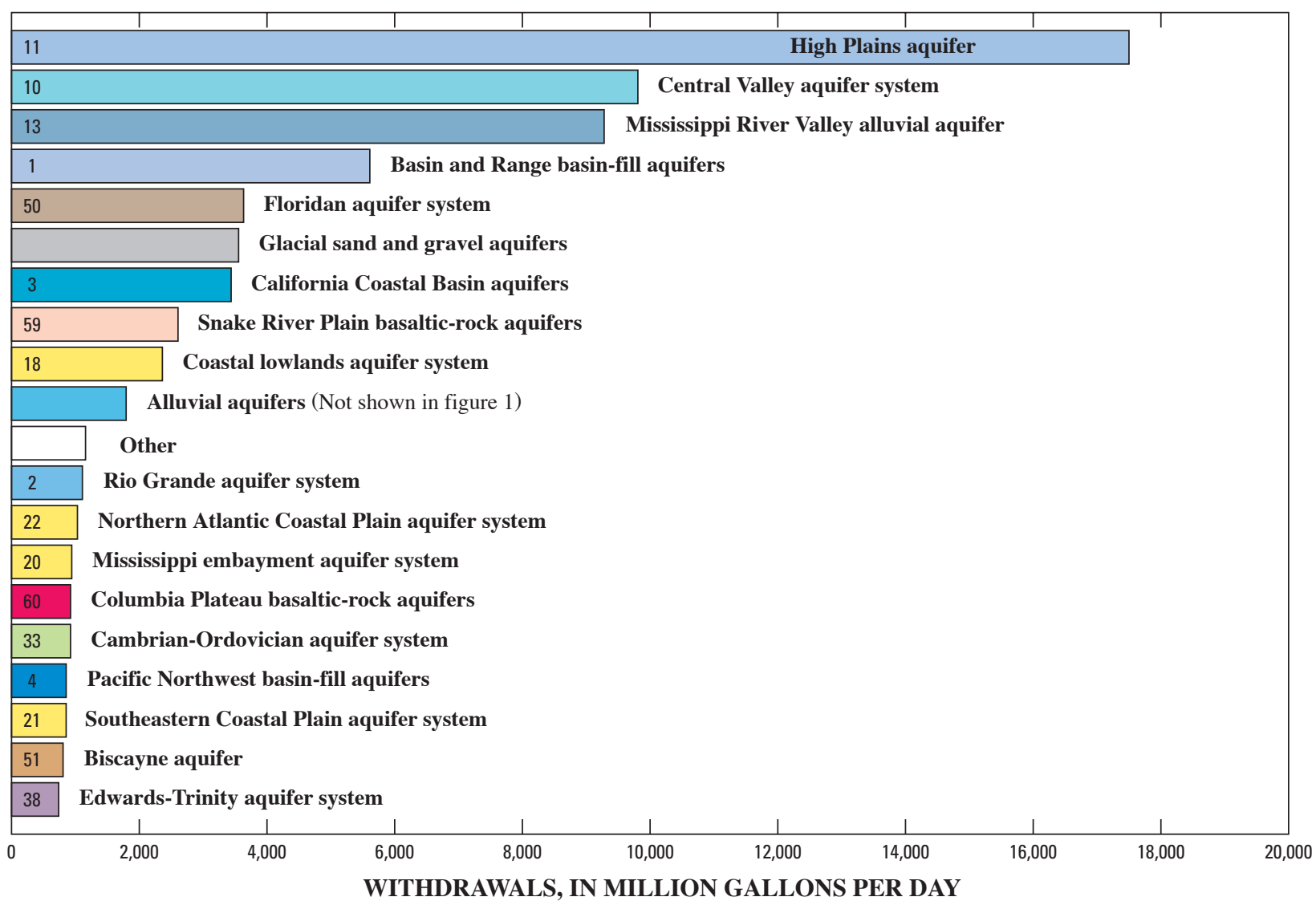

Figure 5. Aquifers that provided most of the total withdrawals for irrigation, public-supply, and self-supplied industrial water uses in the United States during 2000 


\section{WATER USE BY CATEGORY}

Irrigation water use is water that is applied by an irrigation system to sustain plant growth in any agricultural or horticultural practice. It also includes water used for frost protection, application of chemicals, weed control, field preparation, crop cooling, harvesting, dust suppression, leaching of salts from the root zone, and water lost in conveyance. Irrigation of golf courses, parks, nurseries, turf farms, cemeteries, and other self-supplied landscape-watering uses also are considered irrigation water uses. However, water that is provided by a public-supply system for such landscape irrigation purposes is included as part of public-supply withdrawals. Irrigation water use includes self-supplied ground-water withdrawals and deliveries from irrigation companies, irrigation districts, cooperatives, or governmental entities.

Ground-water withdrawals for irrigation in 2000 were $56,900 \mathrm{Mgal} / \mathrm{d}$, or $63,800 \mathrm{taf} / \mathrm{yr}$, which accounted for 74 percent of total withdrawals from all aquifers for irrigation, public-supply, and self-supplied industrial uses. Unconsolidated and semiconsolidated sand and gravel aquifers provided 86 percent of the total irrigation withdrawals from all aquifers (figure 6). Igneous and metamorphic-rock aquifers provided about 7 percent of the total irrigation withdrawals, and carbonate-rock aquifers provided about 4 percent. Sandstone and sandstone and carbonate-rock aquifers each provided about 1 percent of total irrigation withdrawals.
Four principal aquifers, the High Plains aquifer $(17,000 \mathrm{Mgal} / \mathrm{d})$, Mississippi River Valley alluvial aquifer $(9,150 \mathrm{Mgal} / \mathrm{d})$, Central Valley aquifer system $(8,910 \mathrm{Mgal} / \mathrm{d})$, and the Basin and Range basin-fill aquifers (4,550 Mgal/d), provided 70 percent of total irrigation withdrawals. All of these aquifers are unconsolidated and semiconsolidated sand and gravel aquifers (table 1), and all are located in States where significant volumes of ground water are used for irrigation (table 2, back of report).

Some States depend on withdrawals from primarily one principal aquifer for irrigation; the following is a list of the States that accounted for particularly large withdrawals for irrigation. Withdrawals of $8,910 \mathrm{Mgal} / \mathrm{d}$ from the Central Valley aquifer system in California were the largest irrigation withdrawals from any single aquifer in any State (table 2). This amount represented more than 76 percent of the total ground-water withdrawals for irrigation in California. Withdrawals of 7,050 Mgal/d from the High Plains aquifer in Nebraska ranked second in the Nation. This amount represented 41 percent of total irrigation withdrawals from the High Plains aquifer and 95 percent of total ground-water withdrawals for irrigation in Nebraska. Irrigation withdrawals from the High Plains aquifer in Texas $(5,070 \mathrm{Mgal} / \mathrm{d})$ and Kansas (2,830 Mgal/d), which ranked fourth and fifth, respectively, and, combined with Nebraska, accounted for 88 percent of total irrigation withdrawals from the High Plains aquifer. Withdrawals of 6,320 Mgal/d from the Mississippi River Valley alluvial aquifer in Arkansas ranked third in the Nation and represented 69 percent of the total withdrawals for irrigation from that aquifer. Withdrawals of $2,680 \mathrm{Mgal} / \mathrm{d}$ from the Basin and Range basin-fill aquifers in Arizona ranked sixth in the Nation and represented 59 percent of the total withdrawals from the Basin and Range basin-fill aquifers for irrigation.

Aquifers in the igneous and metamorphic-rock lithology are used primarily for irrigation purposes in the Pacific Northwest, where highly permeable and productive basaltic-rock aquifers predominate. Major aquifers in this lithology include the Snake River Plain basaltic-rock aquifers and the Columbia Plateau basaltic-rock aquifers. The Snake

Figure 6. Total ground-water withdrawals, by lithologic group, for irrigation water use in the United States, 2000 


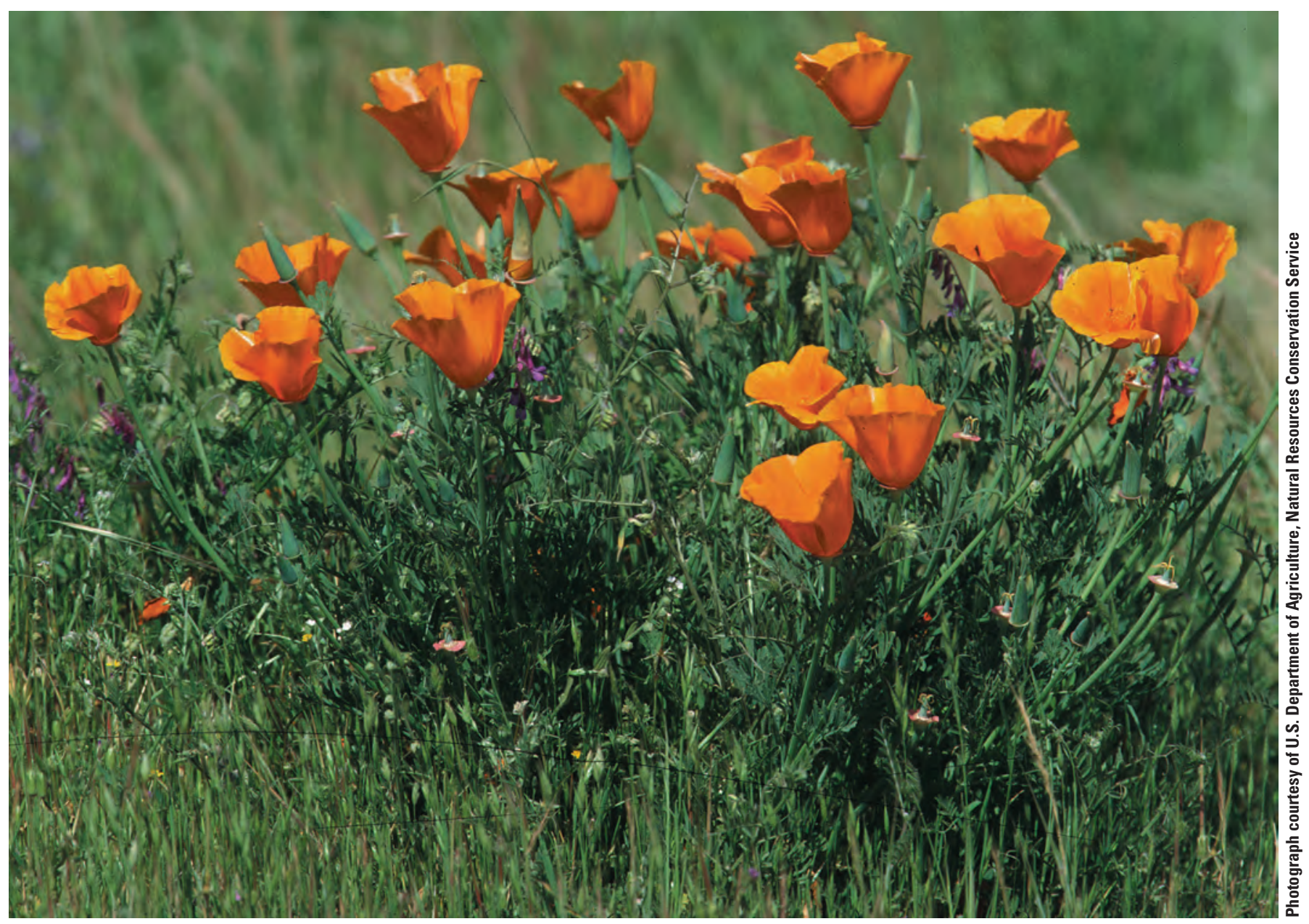

River Plain basaltic-rock aquifers alone provided 66 percent of the total irrigation withdrawals from this lithology. Irrigation withdrawals of 2,490 Mgal/d from the Snake River Plain basaltic-rock aquifer in Idaho were the seventh largest in the Nation.

The California Coastal Basin aquifers in California supplied 1,760 Mgal/d for irrigation, which represented the eighth largest withdrawals in the Nation and 15 percent of California's total irrigation withdrawals. The California Coastal Basin aquifers are located entirely within California.
Carbonate-rock aquifers vary in extent, productivity, and suitability of water quality for irrigation uses. Withdrawals from the Floridan aquifer system provided 76 percent of the total irrigation withdrawals from all aquifers in the carbonaterock lithology. Irrigation withdrawals of 1,460 Mgal/d from the Floridan aquifer system in Florida were the ninth largest in the Nation and represented most of the total irrigation withdrawals from the Floridan aquifer system. 
Public-supply water is withdrawn by public and private water systems and delivered to domestic, commercial, and other types of customers for their uses. In addition, some public-supply water is used for water treatment and in wastewater treatment facilities; it may be used for public services such as pools, parks, golf courses, and city buildings, or lost through system leaks, unmetered services, and maintenance activities. Public-supply facilities include water systems that provide water to at least 25 people or have a minimum of 15 connections.

Ground-water withdrawals for public supply in 2000 were $16,000 \mathrm{Mgal} / \mathrm{d}$, (17,900 taf/yr), which accounted for about 21 percent of total withdrawals from all aquifers for irrigation, public-supply, and self-supplied industrial uses. Unconsolidated and semiconsolidated sand and gravel aquifers provided 64 percent of total public-supply withdrawals, or 10,300 Mgal/d (figure 7). Carbonate-rock aquifers provided 17 percent, or $2,750 \mathrm{Mgal} / \mathrm{d}$. Sandstone aquifers (1,080 Mgal/d), sandstone and carbonate-rock aquifers (745 Mgal/d) and igneous and metamorphic-rock aquifers (751 Mgal/d) provided about 7 percent, 5 percent, and 5 percent, respectively.

States with the largest public-supply ground-water withdrawals were California, Florida, and Texas. Publicsupply withdrawals of $1,580 \mathrm{Mgal} / \mathrm{d}$ from the California
Coastal Basin aquifers in California were the largest public-supply withdrawals from any aquifer in any single State. Withdrawals of 1,160 Mgal/d from the Floridan aquifer system in Florida ranked second and accounted for 87 percent of the total public-supply withdrawals from that aquifer system. Withdrawals of $531 \mathrm{Mgal} / \mathrm{d}$ from the Coastal lowlands aquifer system in Texas ranked third and accounted for 53 percent of the total public-supply withdrawals from that aquifer system.

Within the unconsolidated and semiconsolidated sand and gravel lithology, the glacial sand and gravel aquifers are the primary aquifers used for public supply. The glacial sand and gravel aquifers provided 12 percent $(1,950 \mathrm{Mgal} / \mathrm{d})$ of the total public-supply withdrawals from all aquifers, more than any other aquifer system. They encompass parts or all of 22 States in the Northeastern and upper Mid-western United States (figure 1). The largest withdrawals from these aquifers were in Ohio (312 Mgal/d) and Indiana (309 Mgal/d) (table 2). Other important unconsolidated and semiconsolidated sand and gravel aquifers are the California Coastal Basin aquifers (1,580 Mgal/d), Coastal lowlands aquifer system (1,010 Mgal/d), and the Basin and Range basin-fill aquifers (1,010 Mgal/d).

Major aquifers in the carbonate-rock lithology are the Floridan aquifer system, Biscayne aquifer, Valley and Ridge carbonate-rock aquifers, and Silurian-

Devonian aquifers. Combined, these aquifers supplied 87 percent of all public-supply withdrawals from all carbonate-rock aquifers. The Floridan aquifer system supplied most of these withdrawals.

Aquifers in the sandstone, sandstone and carbonate, and igneous and metamorphic-rock lithologies were used much less extensively for public-supply water, however a few aquifer systems were large public-supply sources in two States. The Cambrian-Ordovician aquifer system supplied more than half of the total public-supply withdrawals from all sandstone aquifers; most of the withdrawals (209 Mgal/d) were in Minnesota. The Edwards-Trinity aquifer system supplied more than half of total public-supply withdrawals from the sandstone and carbonate-rock lithology; almost all of the public-supply withdrawals from the EdwardsTrinity aquifer were in Texas (402 Mgal/d).

The igneous and metamorphic-rock lithology is represented primarily by basaltic-
Figure 7. Total ground-water withdrawals, by lithologic group, for public-supply water use in the United States, 2000 
rock aquifers in Western States, but only two aquifers were significant sources of public-supply water. The volcanic-rock aquifers in Hawaii and the Columbia Plateau basaltic-rock aquifers accounted for 62 percent of the public-supply withdrawals from this lithology. Nearly all of Columbia Plateau basaltic-rock aquifer withdrawals for public supply were in the State of Washington (196 Mgal/d).

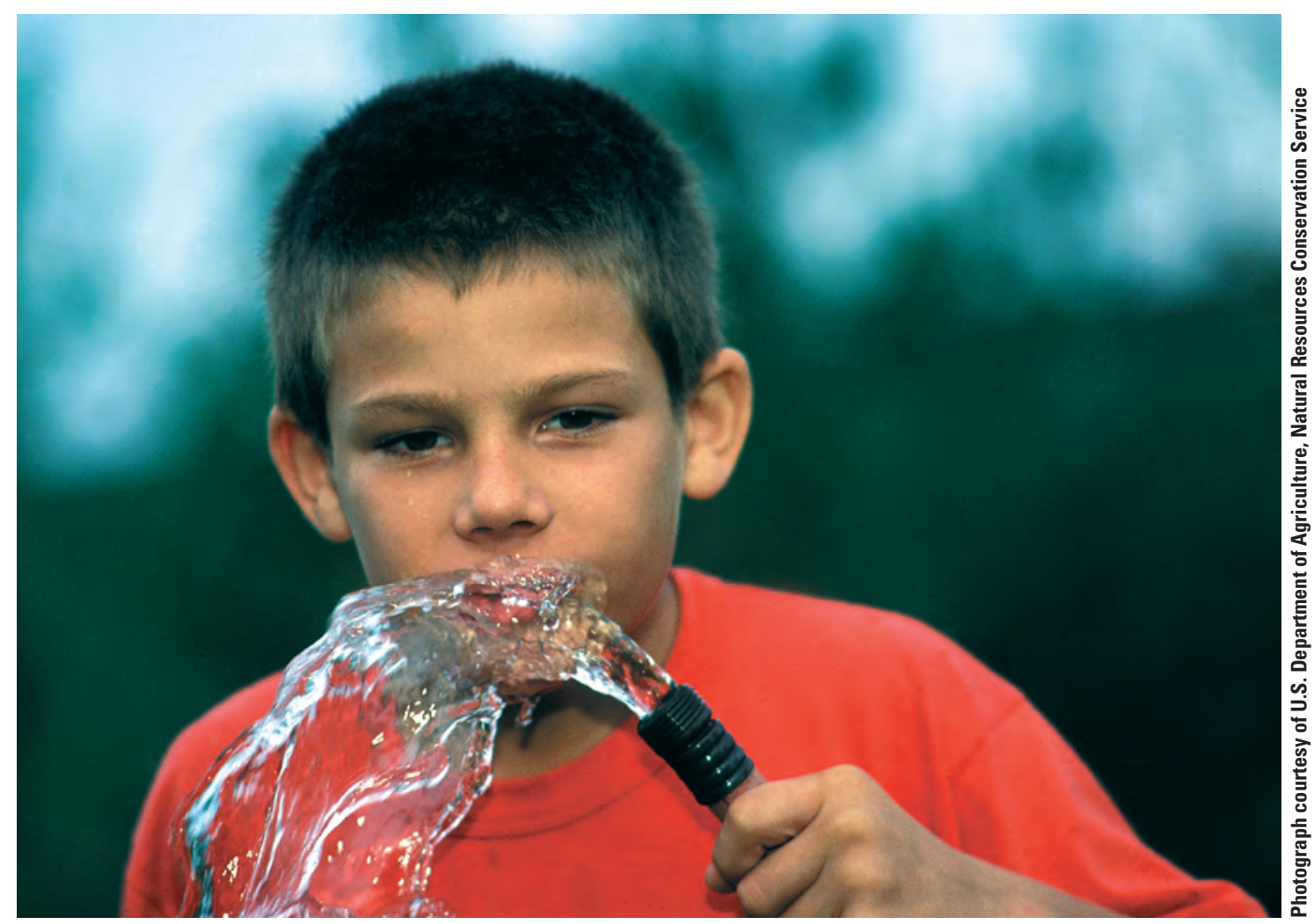


Industrial water is used for processing, washing, diluting, or transporting a product; it also may be incorporated into a product. Other uses include cooling and sanitation in manufacturing facilities. The water may be delivered from a public supplier or be self-supplied; however, this report refers only to self-supplied ground-water withdrawals.

Self-supplied industrial ground-water withdrawals in 2000 were 3,570 Mgal/d (4,000 taf/yr), which accounted for 5 percent of the total withdrawals from all aquifers for irrigation, public-supply, and self-supplied industrial uses. Unconsolidated and semiconsolidated sand and gravel aquifers provided 64 percent of total self-supplied industrial withdrawals. Carbonate aquifers provided about 16 percent of the total, and sandstone aquifers provided 10 percent. Sandstone and carbonate-rock aquifers provided about 5 percent of the total, and igneous and metamorphic-rock aquifers provided about 3 percent of the total (figure 8).

The four aquifers that supplied 46 percent of the total withdrawals for self-supplied industrial uses were glacial sand and gravel aquifers (583 Mgal/d), Coastal lowlands aquifer system (425 Mgal/d), Floridan aquifer system (385 Mgal/d), and Cambrian-Ordovician aquifer system (251 Mgal/d) (table 1). Withdrawals in Ohio (101 Mgal/d), Indiana (94.9 Mgal/d), and Illinois (91.9 Mgal/d) constituted about 50 percent of the self-supplied industrial withdrawals from the glacial sand and gravel aquifers (table 2). These States ranked sixth, seventh, and eighth in the Nation, respectively, for self-supplied industrial withdrawals. Withdrawals of $199 \mathrm{Mgal} / \mathrm{d}$ in Louisiana from the Coastal lowlands aquifer system ranked second in the Nation and accounted for nearly half of the self-supplied industrial withdrawals from that aquifer system. Withdrawals in Georgia (205 Mgal/d) and Florida (173 Mgal/d) accounted for nearly all (99 percent) of the total self-supplied industrial withdrawals from the Floridan aquifer system. Withdrawals of $134 \mathrm{Mgal} / \mathrm{d}$ in Iowa from the Cambrian-Ordovician aquifer system ranked fourth in the Nation and accounted for 53 percent of the total self-supplied industrial withdrawals from that aquifer system.

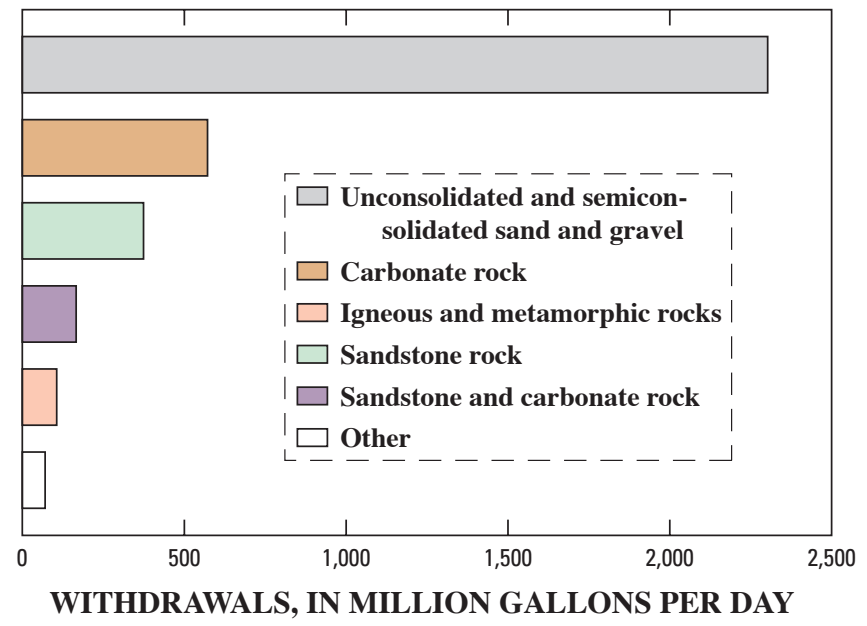

Figure 8. Total ground-water withdrawals, by lithologic group, for self-supplied industrial water use in the United States, 2000 
[This page intentionally left blank] 


\section{Water Use from Selected Principal Aquifers}

High Plains Aquifer

Central Valley Aquifer System

Mississippi River Valley Alluvial Aquifer

Basin and Range Basin-Fill Aquifers

Floridan Aquifer System

Glacial Sand and Gravel Aquifers

California Coastal Basin Aquifers

Snake River Plain Basaltic-Rock Aquifers

Coastal Lowlands Aquifer System 
[This page intentionally left blank] 


\section{High Plains Aquifer System}

The High Plains aquifer underlies a 174,000- $\mathrm{mi}^{2}$ area in parts of the eight States of Colorado, Kansas, Nebraska, New Mexico, Oklahoma, South Dakota, Texas, and Wyoming. It is composed of extensive, hydraulically connected geologic units of blanket-like sand and gravel of late Tertiary to Quaternary age (McGuire and others, 2003).

This was the most intensively used aquifer in 2000; total ground-water withdrawals were nearly $17,500 \mathrm{Mgal} / \mathrm{d}$ (19,600 taf/yr). Withdrawals from the High Plains aquifer accounted for 23 percent of total withdrawals from all aquifers, and nearly 30 percent of total irrigation withdrawals from all aquifers.

Almost 97 percent of the total withdrawals from the High Plains aquifer were used for irrigation (17,000 Mgal/d); publicsupply withdrawals accounted for 2 percent (389 Mgal/d); and self-supplied industrial withdrawals accounted for only 1 percent (99.2 Mgal/d). Nebraska, Texas, and Kansas used 88 percent of the total withdrawals, almost entirely for irrigation.

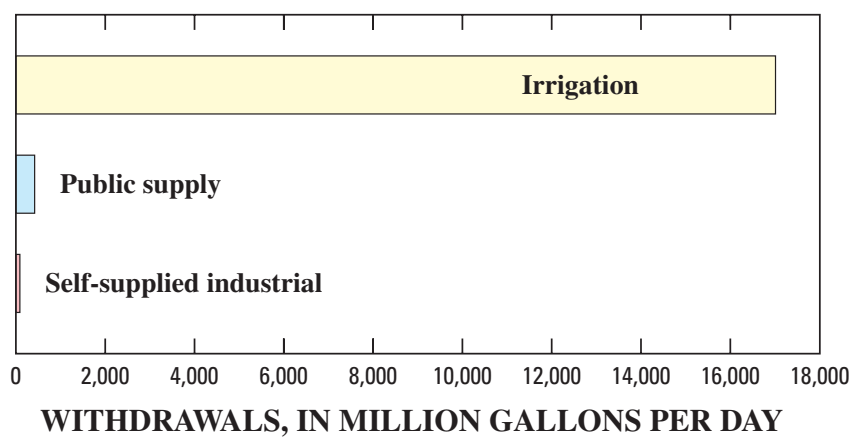

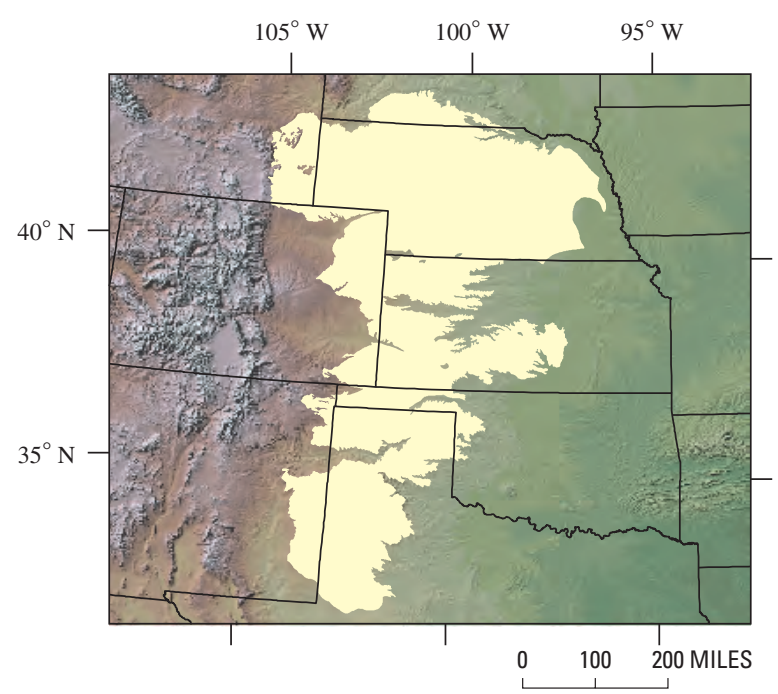

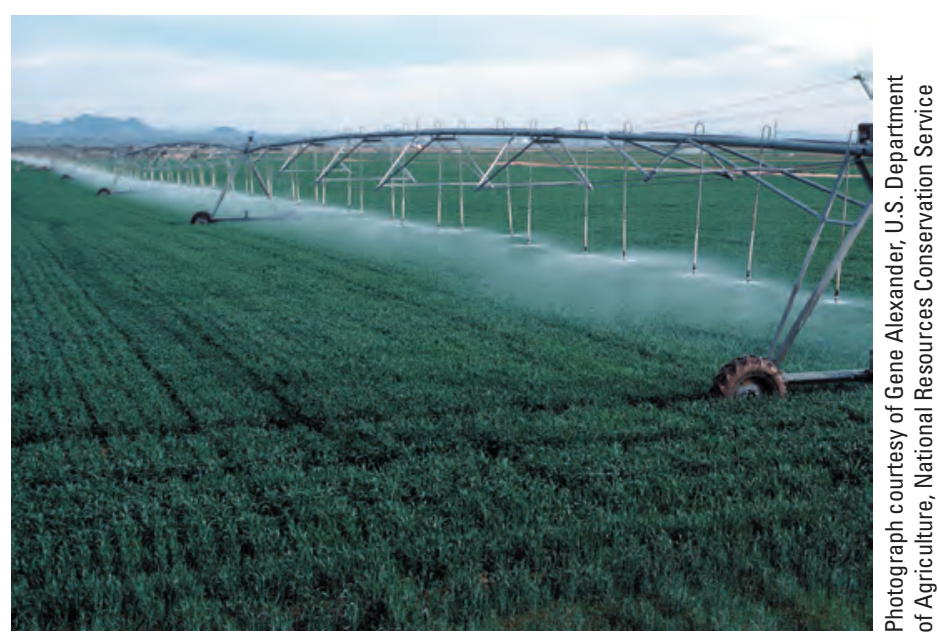

Center pivot on wheat grown in Yuma County, Colorado, which is located along the Kansas and Nebraska State lines

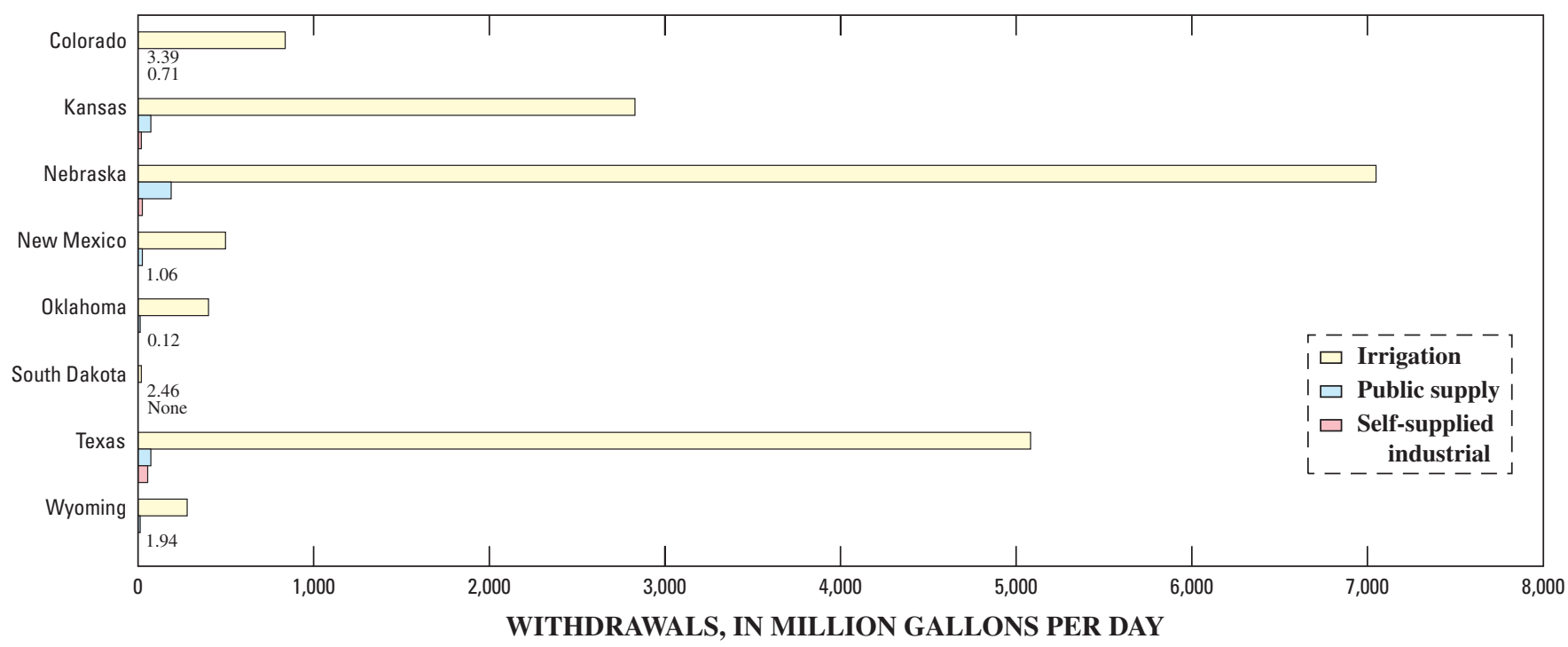




\section{Central Valley Aquifer System}

The Central Valley aquifer system is located entirely within California's Central Valley, a structural trough about $400 \mathrm{mi}$ in length, 20 to $70 \mathrm{mi}$ in width, and more than $20,000 \mathrm{mi}^{2}$ in extent. The Central Valley aquifer system consists primarily of sand and gravel deposits with significant amounts of silt and clay in some areas. These deposits eroded from older rocks at the margins of the valley and average about 2,400 ft in thickness but are as much as $9,000 \mathrm{ft}$ thick in the southern end of the valley. The deposits range from Tertiary to Quaternary in age (Williamson and others, 1989).

Total ground-water withdrawals of $9,810 \mathrm{Mgal} / \mathrm{d}$ (11,000 taf/yr) for irrigation, public-supply, and selfsupplied industrial water uses were the second largest in the United States. Withdrawals from this aquifer system accounted for about 13 percent of the total ground-water withdrawals from all aquifers and about 16 percent of total irrigation withdrawals from all aquifers.

The Central Valley in California is one of the largest irrigated agricultural areas in the United States and produces most of the nuts, fruits, and vegetables for the Nation. Favorable climate and soil, and the availability of water enable crops to be grown year round. In 2000, about 91 percent of the total withdrawals from the Central Valley aquifer system were for irrigation (8,910 Mgal/d), 9 percent ( $839 \mathrm{Mgal} / \mathrm{d}$ ) were for public supply, and less than 1 percent $(58.9 \mathrm{Mgal} / \mathrm{d}$ ) was for self-supplied industrial use.

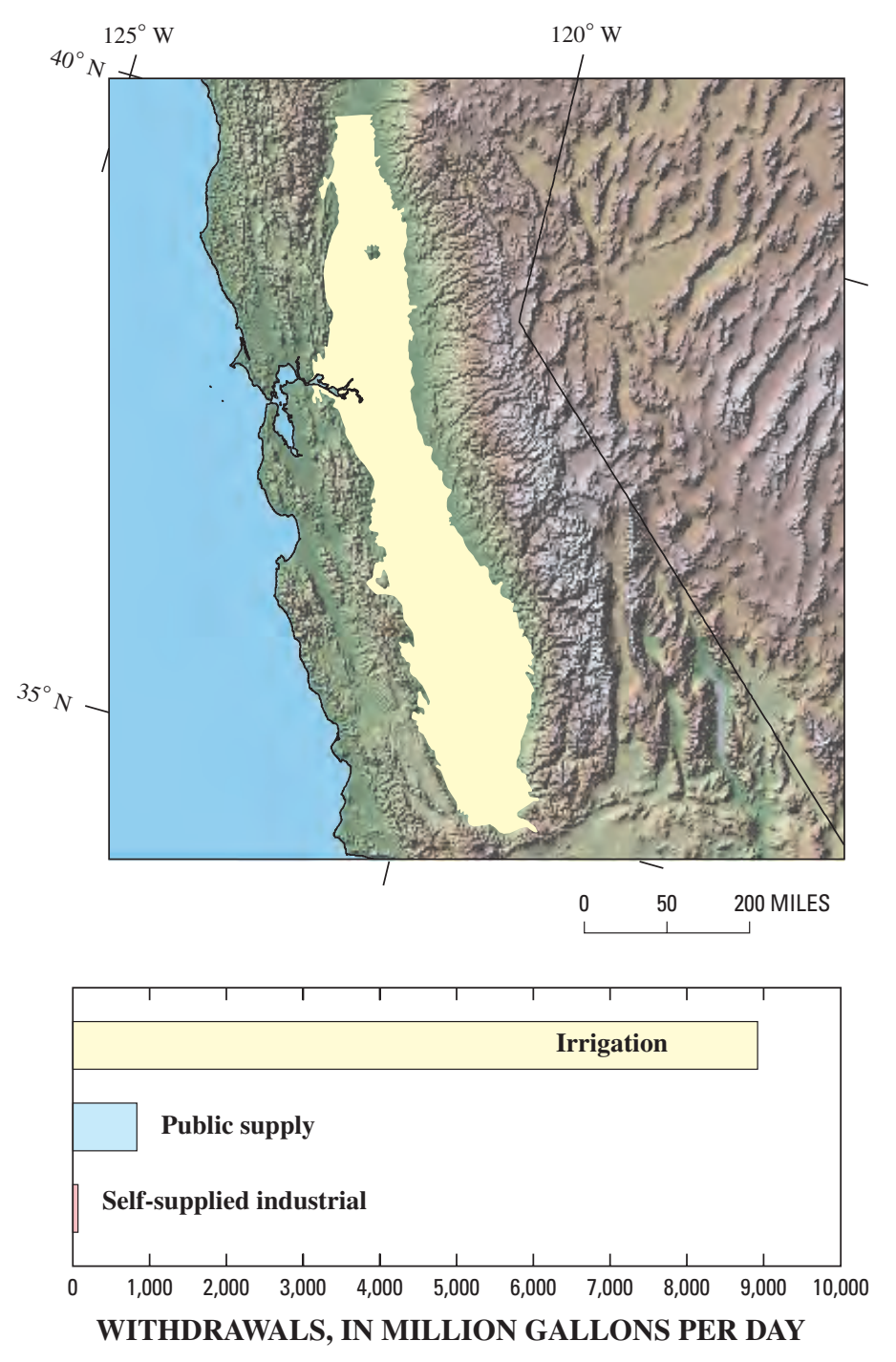

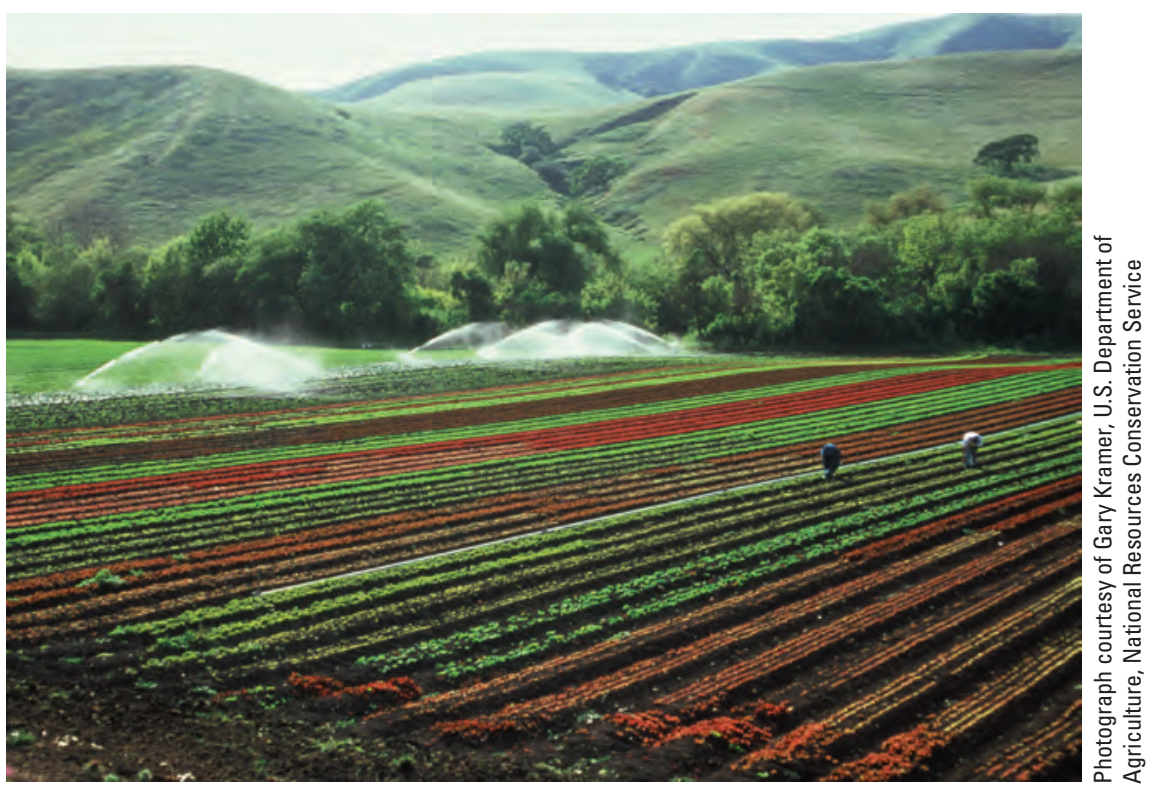

Lettuce crop in central California 


\section{Mississippi River Valley Alluvial Aquifer}

The Mississippi River Valley alluvial aquifer underlies a 33,000- $\mathrm{mi}^{2}$ area and is located mostly within Arkansas, Louisiana, Mississippi, and Missouri, and to a much lesser extent in Illinois, Kentucky, and Tennessee (Renken, 1998). It is composed of highly permeable layers of Quaternaryage deposits of sand, gravel, silt, and some clay.

Withdrawals of 9,290 Mgal/d (10,400 taf/yr) from the Mississippi River Valley alluvial aquifer ranked third in the Nation for total withdrawals from all aquifers and accounted for about 12 percent of the total. More than 98 percent of the total withdrawals from the Mississippi River Valley alluvial aquifer were for irrigation $(9,150 \mathrm{Mgal} / \mathrm{d})$, almost 70 percent of which was used in Arkansas.
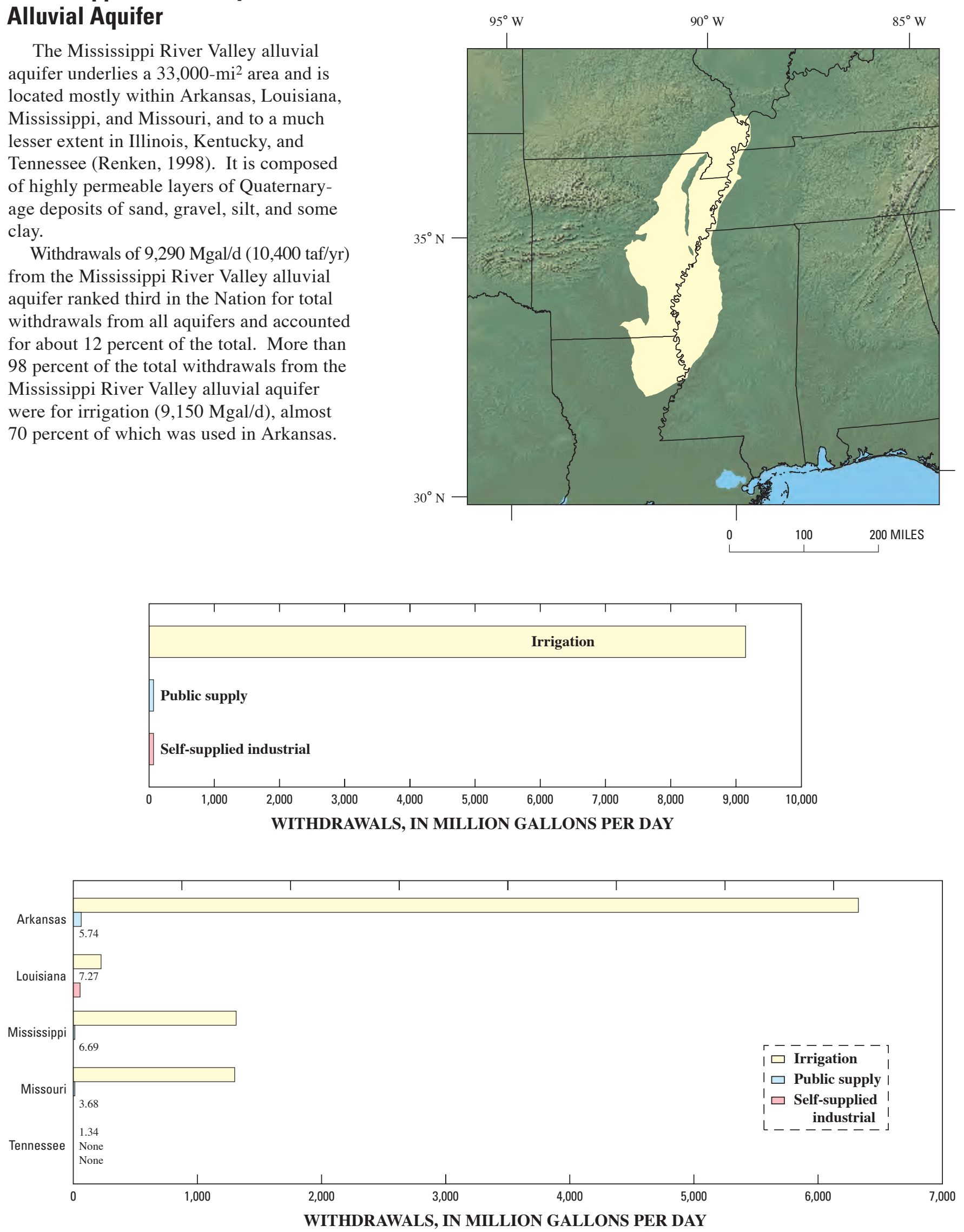


\section{Basin and Range Basin-Fill Aquifers}

The Basin and Range basin-fill aquifers are mostly in Nevada and parts of eastern and southern California but also extend into eastern Utah and southern Arizona. They are composed of thick deposits of unconsolidated sand and gravel of Tertiary and Quaternary age, which were eroded from the surrounding mountains and deposited in individual alluvial basins separated by mountain ranges (Planert and Williams, 1995).

The Basin and Range basin-fill aquifers are by far the most productive aquifers in Arizona, Nevada, and Utah. Total withdrawals from these aquifers were 5,620 Mgal/d (6,300 taf/yr), which constituted about 7 percent of withdrawals from all aquifers. Arizona used more than half $(3,060 \mathrm{Mgal} / \mathrm{d}$, or 54 percent) of the total withdrawals from this aquifer. Withdrawals of $4,550 \mathrm{Mgal} / \mathrm{d}$ for irrigation use accounted for 81 percent of the total withdrawals from the Basin and Range basin-fill aquifers. Arizona used almost 60 percent $(2,680 \mathrm{Mgal} / \mathrm{d})$ of the total irrigation withdrawals from this aquifer. Public-supply withdrawals amounted to about 18 percent of the total aquifer withdrawals $(1,010 \mathrm{Mgal} / \mathrm{d})$, more than 80 percent of which were used in Arizona, California, and Utah.
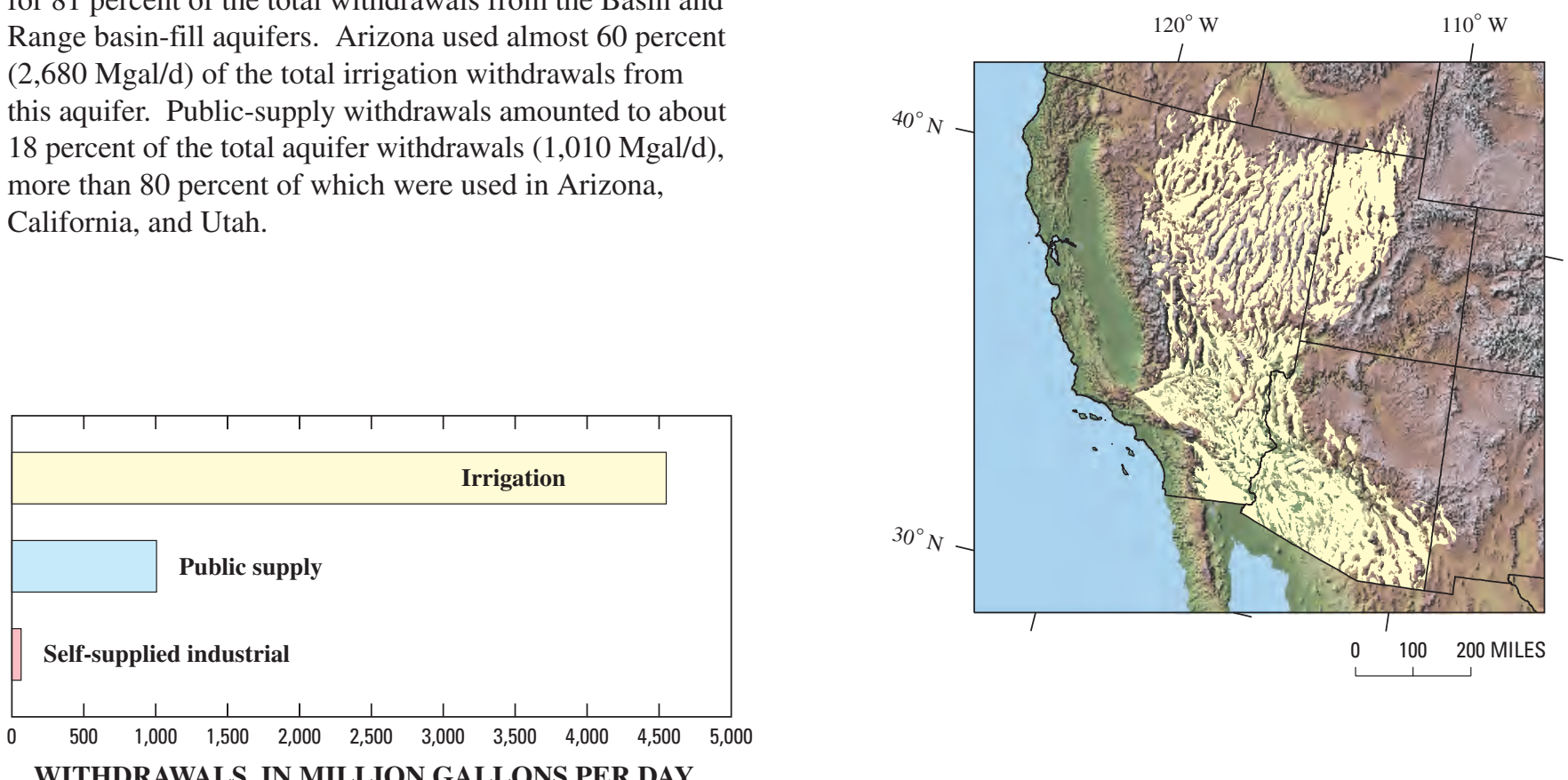

WITHDRAWALS, IN MILLION GALLONS PER DAY

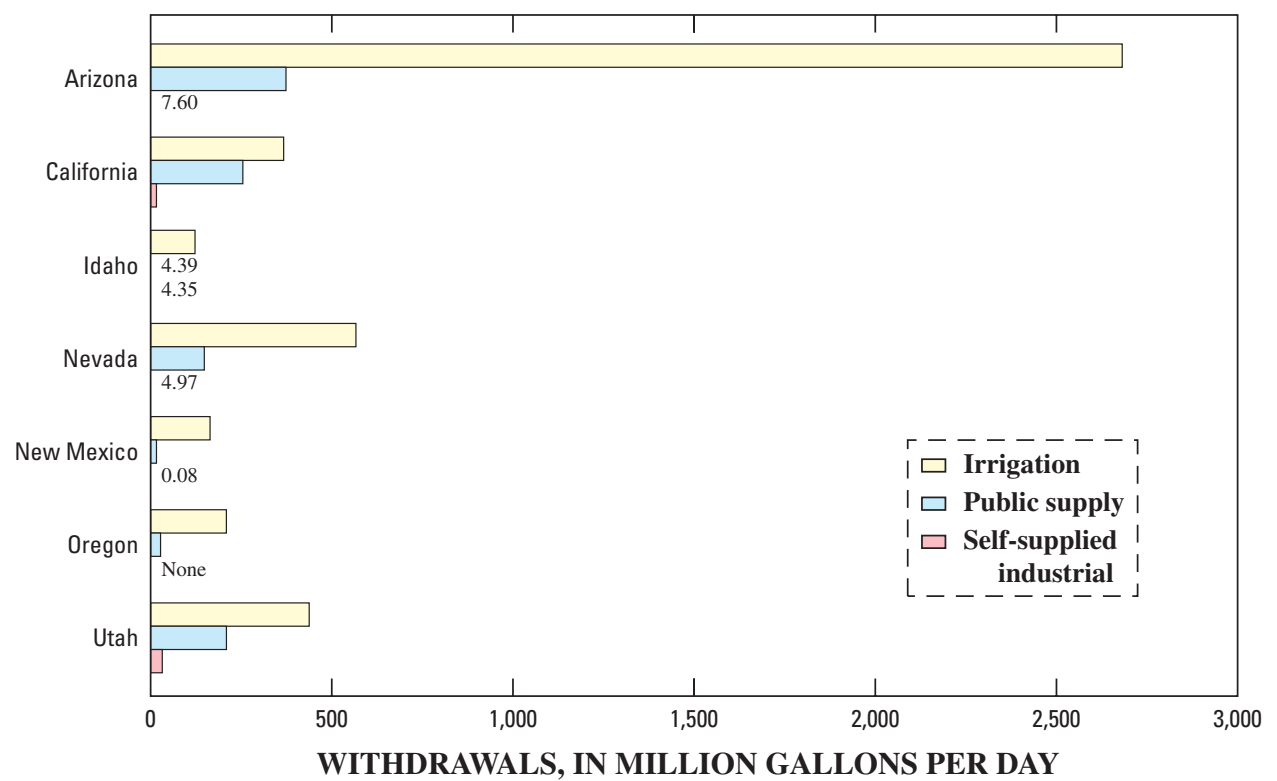




\section{Floridan Aquifer System}

The Floridan aquifer system underlies an area of about 100,000 $\mathrm{mi}^{2}$ in southern Alabama, southern Georgia, southern South Carolina, and all of Florida, and is one of the most productive aquifers in the world (Miller, 1990). The Floridan aquifer system is composed of layers of carbonate rocks of Tertiary age, thin near the northern edges and thickening seaward.

Total ground-water withdrawals from the Floridan aquifer system were 3,640 Mgal/d (4,080 taf/yr), which constituted about 5 percent of withdrawals from all aquifers. About 76 percent $(2,790 \mathrm{Mgal} / \mathrm{d})$ of the total withdrawals were in Florida, and 21 percent ( $782 \mathrm{Mgal} / \mathrm{d})$ were in Georgia (table 2). Irrigation water use $(1,930 \mathrm{Mgal} / \mathrm{d})$ accounted for 53 percent of the total withdrawals, primarily in Florida (1,460 Mgal/d) and Georgia (436 Mgal/d). Public supply accounted for 37 percent $(1,330 \mathrm{Mgal} / \mathrm{d})$ of total withdrawals from the Floridan aquifer system, 87 percent of which was used in Florida. Self-supplied industrial water use accounted for the remaining 10 percent of total Floridan aquifer system withdrawals (385 Mgal/d), which were shared mostly between Georgia and Florida.
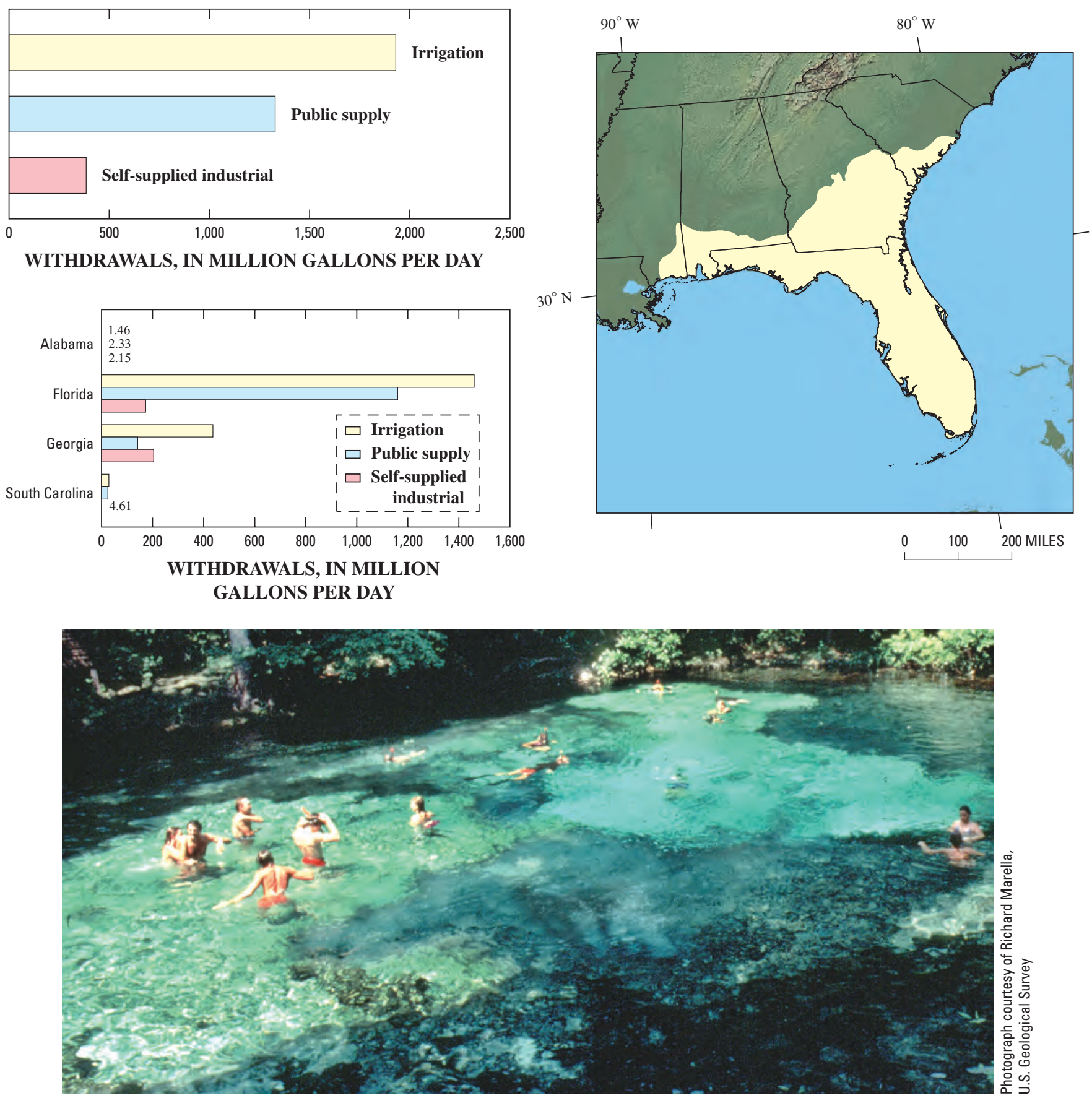

Ginnie Springs, Florida 


\section{Glacial Sand and Gravel Aquifers}

The glacial sand and gravel aquifers are composed of sand, gravel, silt, and clay that were deposited north of the limit of Quaternary continental glaciation and east of the Rocky Mountains. The aquifers include stream-valley alluvium in this area that is largely reworked glacial materials. These types of deposits extend from Maine to Montana and southward almost to Kentucky, encompassing parts or all of 22 North-Central and Northeastern States. Deposits range in thickness from 1,200 ft in parts of Michigan to several hundred feet in buried bedrock valleys in Illinois, Wisconsin, and New York (Grannemann and others, 2000; Miller, 2000).

Glacial sand and gravel aquifers form some of the most productive aquifers in these States because of their high permeability and porosity. Total withdrawals from the glacial sand and gravel aquifers during 2000 were 3,560 Mgal/d (4,000 taf/yr), which constituted almost 5 percent of total withdrawals from all aquifers. About 55 percent $(1,950 \mathrm{Mgal} / \mathrm{d})$ of the total withdrawals from these aquifers were for public supply, and 29 percent (1,020 Mgal/d) were for irrigation. The remaining 16 percent (583 Mgal/d) were for self-supplied industrial use. The glacial sand and gravel aquifers provide the largest public supply and self-supplied industrial withdrawals among all of the principal aquifers.
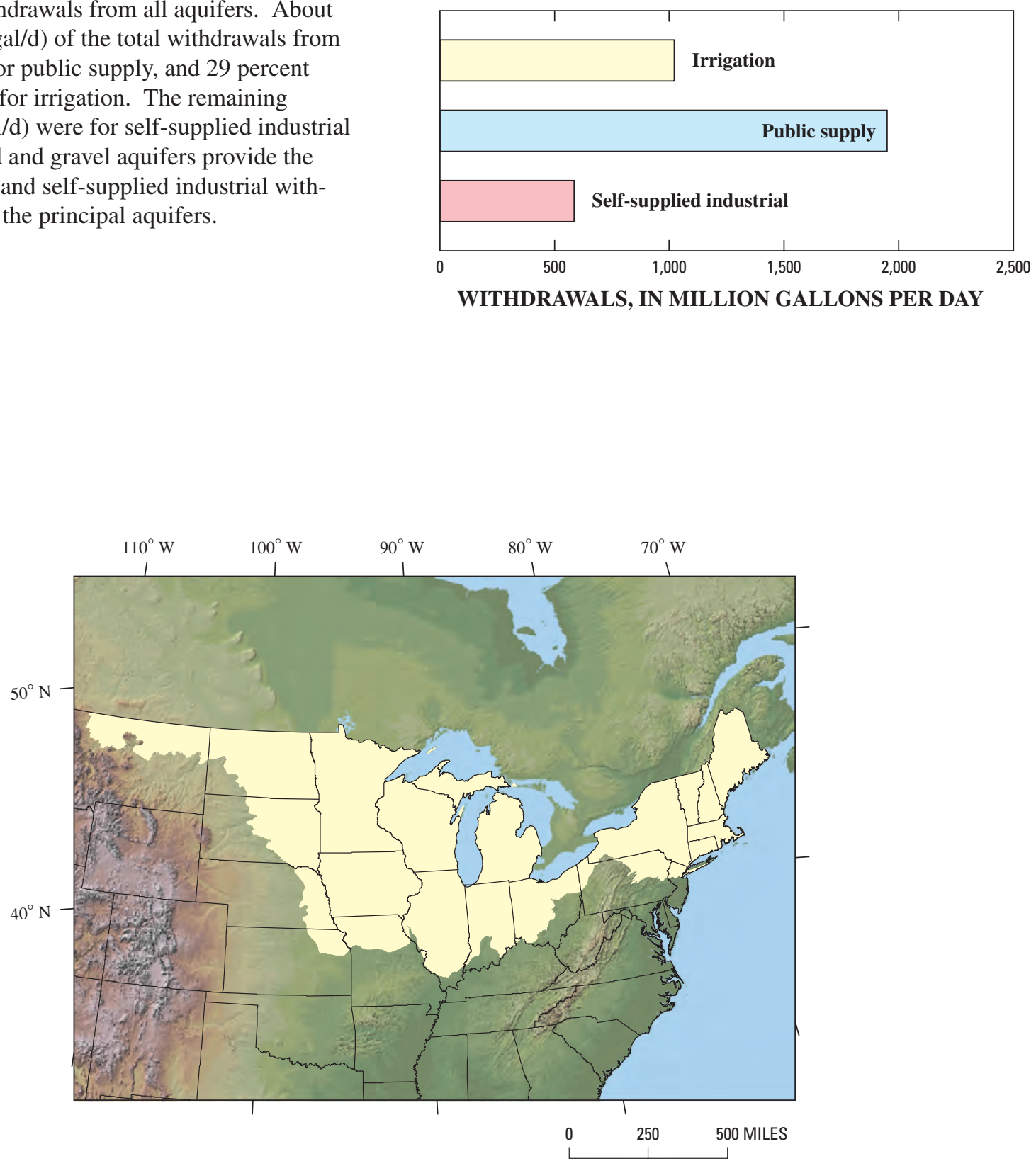


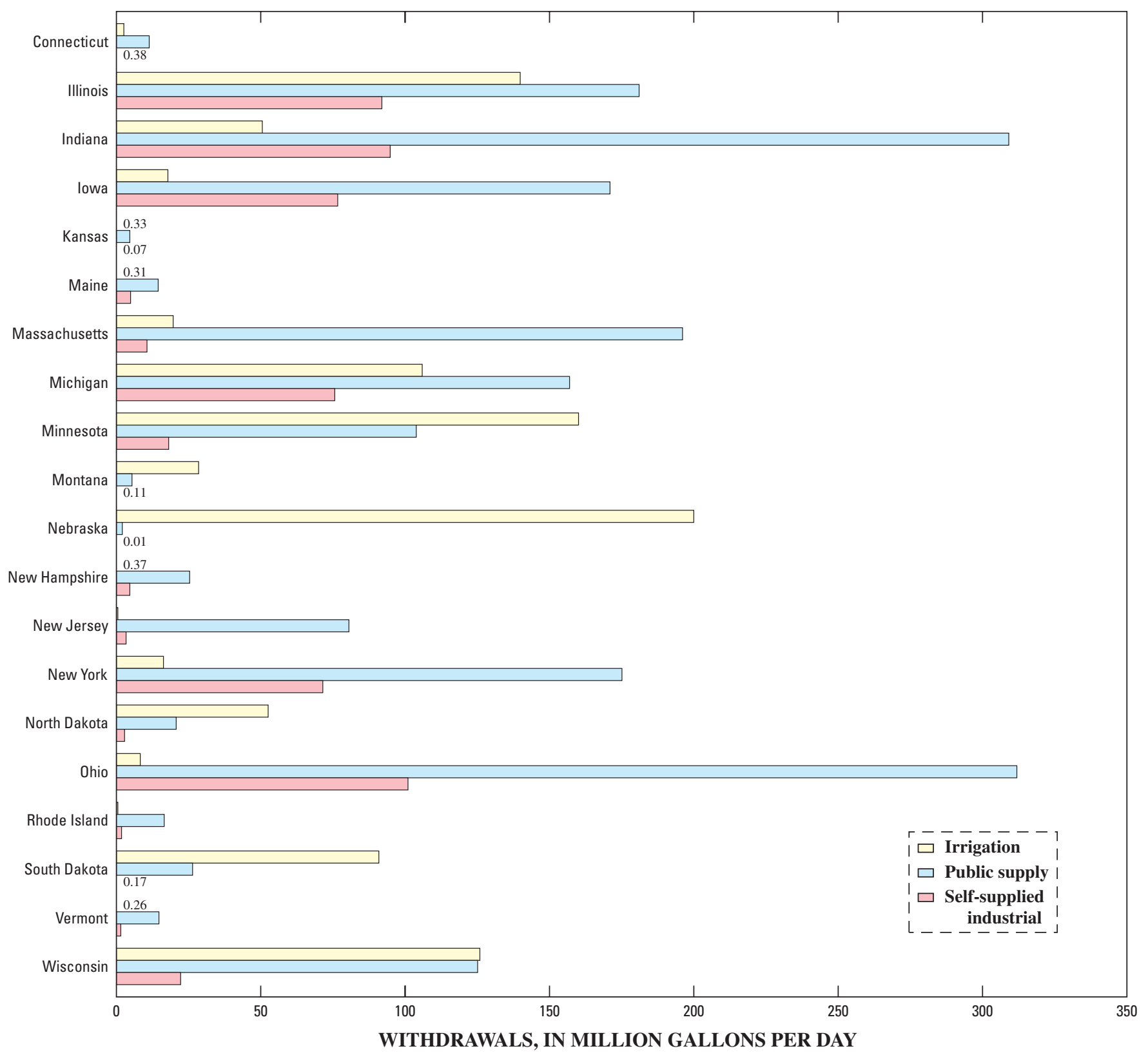




\section{California Coastal Basin Aquifers}

The California Coastal Basin aquifers are present in more than 100 basins in coastal areas from northern to southern California (Planert and Williams, 1995). These basins are filled with marine and alluvial sediments and some volcanic deposits; the aquifers are primarily sand and gravel. Two or more aquifers separated by confining units may be present in a basin. Most of the large population centers in California are located in the coastal basins.

Total withdrawals from the California Coastal Basin aquifers were 3,440 Mgal/d (3,860 taf/yr); more than 4 percent of the total withdrawals from all aquifers. Fifty-one percent of the withdrawals were for irrigation $(1,760 \mathrm{Mgal} / \mathrm{d}), 46$ percent were for public supply (1,580 Mgal/d), and 3 percent were for self-supplied industrial use (106 Mgal/d). The California Coastal Basin aquifers provided the second-largest public-supply withdrawals among the principal aquifers.

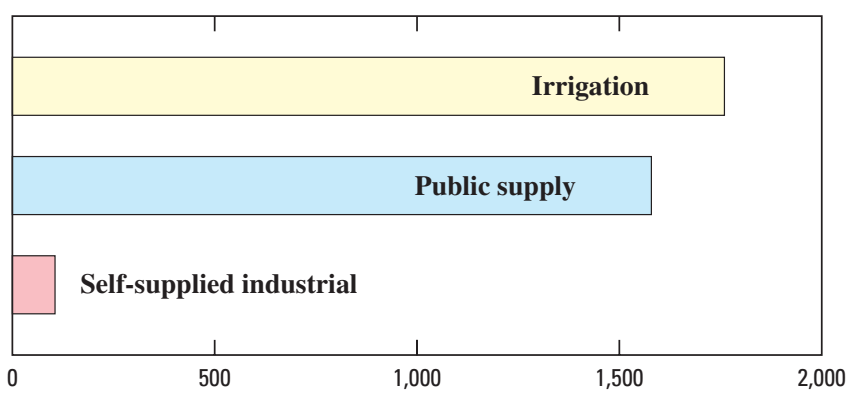

WITHDRAWALS, IN MILLION GALLONS PER DAY

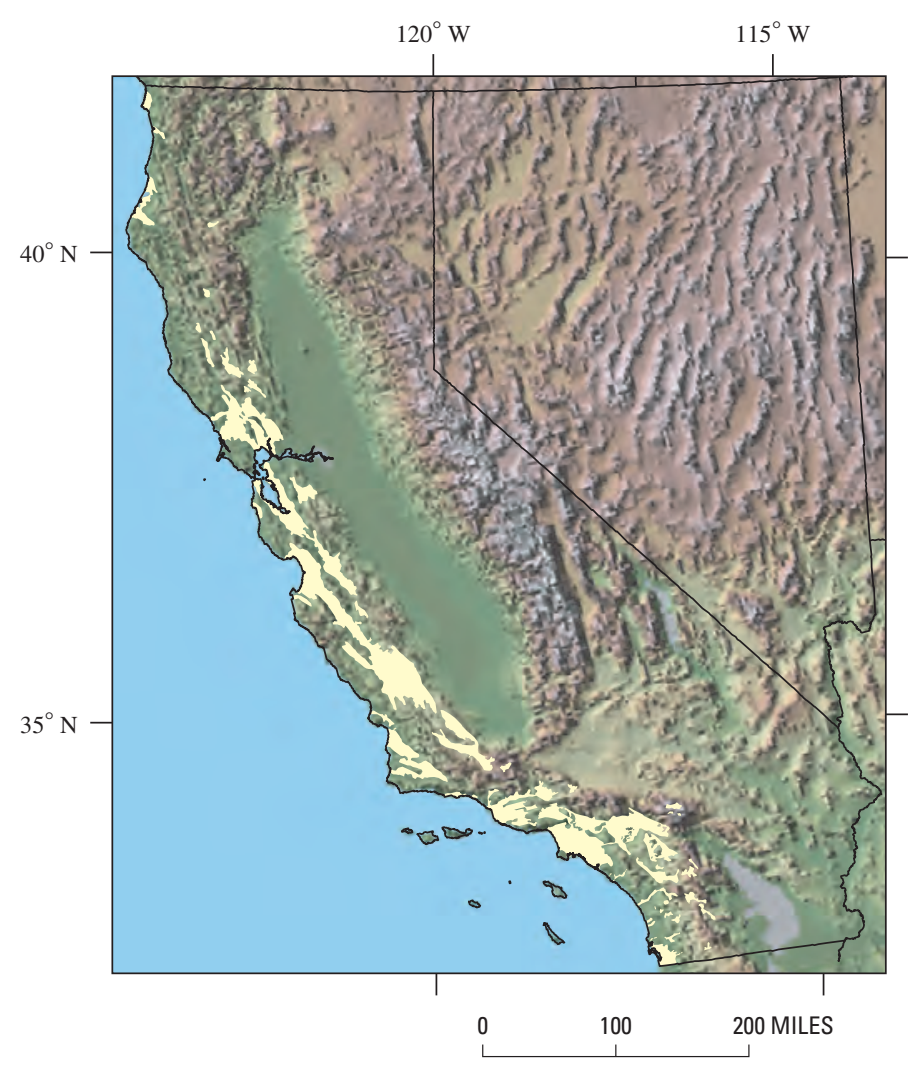

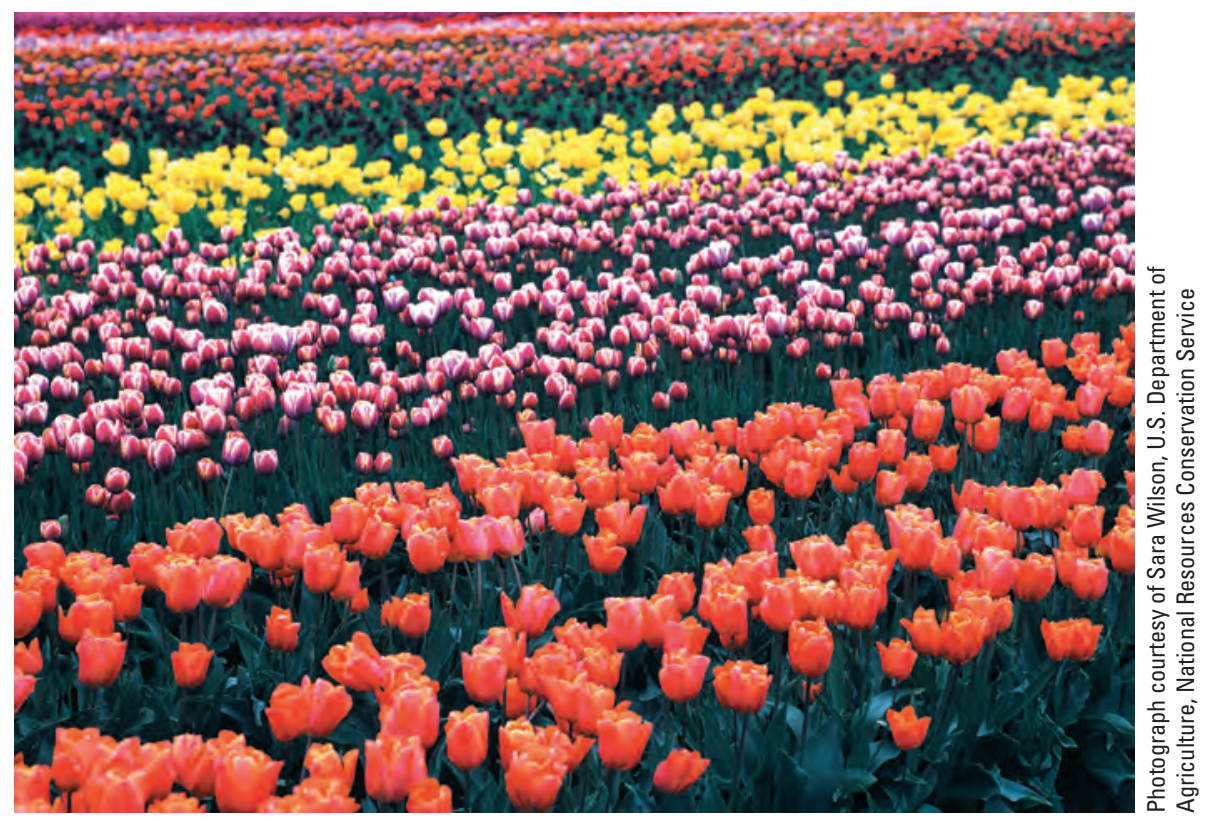




\section{Snake River Plain Aquifers}

The Snake River Plain basaltic-rock aquifers are located in the extensive Pliocene and younger basalt flows that formed a $15,600-\mathrm{mi}^{2}$, crescent-shaped lobe in southern Idaho. The flows are 1,000- to 2,000-ft thick in parts of the eastern half of the plain and are overlain by and interbedded with unconsolidated deposits in some areas. The western half of the plain is composed more of unconsolidated deposits with some Pliocene and younger basalt flows that are not as thick as in the eastern half. Ground water is under unconfined conditions in the unconsolidated deposits and in open spaces and fractures along the tops and bottoms of the stratified basalt flows (Whitehead, 1994).

Total withdrawals from the Snake River Plain basaltic-rock aquifers during 2000 were $2,610 \mathrm{Mgal} / \mathrm{d}$ $(2,930 \mathrm{taf} / \mathrm{yr})$, which represented 3 percent of total withdrawals from all aquifers. Irrigation withdrawals of $2,520 \mathrm{Mgal} / \mathrm{d}$, almost entirely within Idaho $(2,490 \mathrm{Mgal} / \mathrm{d})$, accounted for 97 percent of the total withdrawals from the Snake River Plain basaltic-rock aquifers. Public-supply withdrawals of $70 \mathrm{Mgal} / \mathrm{d}$, all in Idaho, accounted for 3 percent of the total withdrawals from these aquifers.

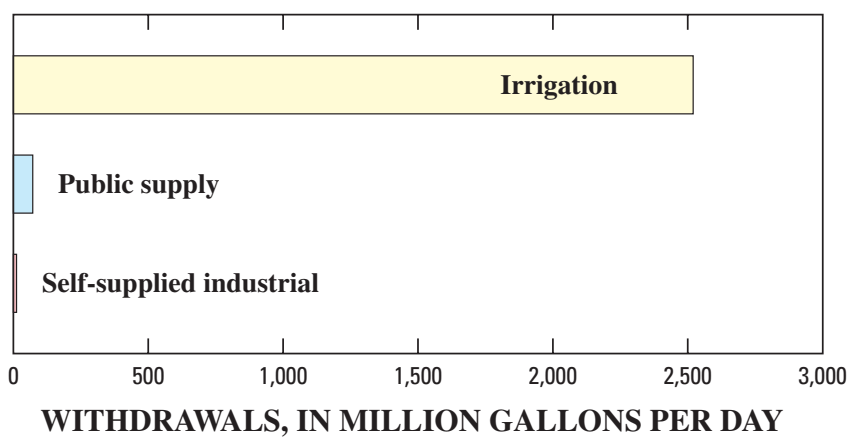

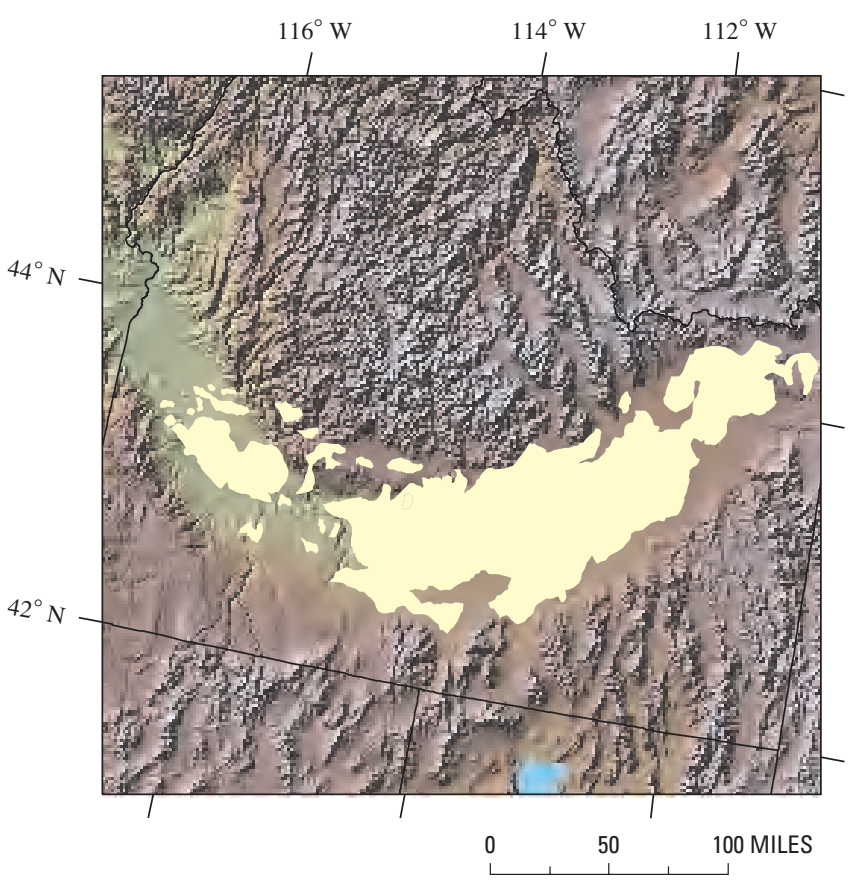

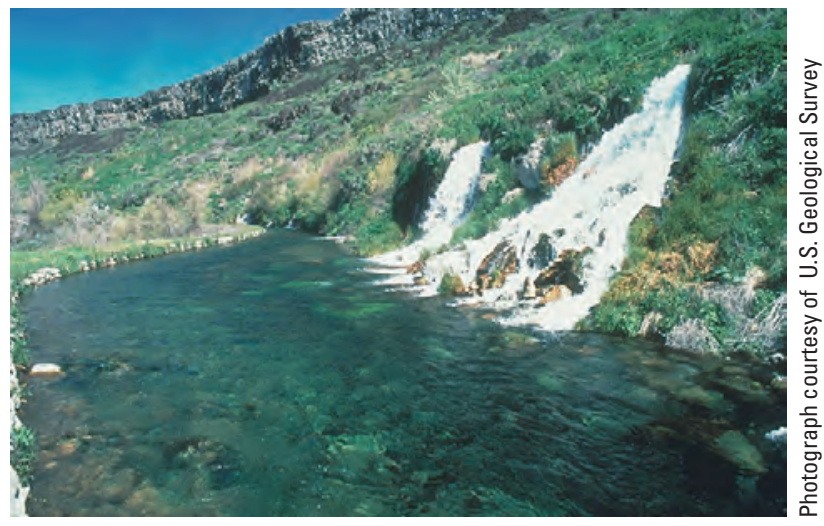

Crystal Springs, located in the Thousand Springs area, southern Idaho

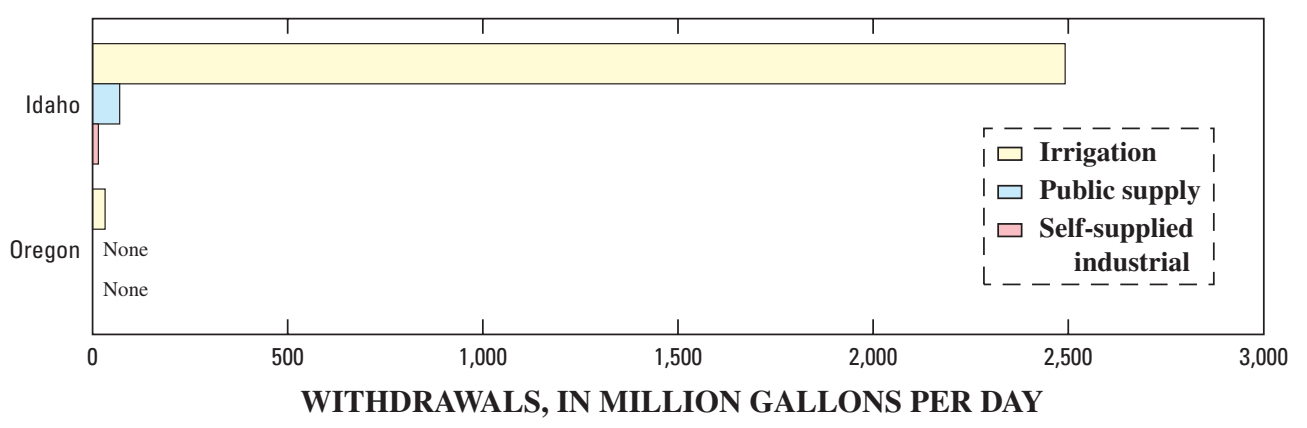




\section{Coastal Lowlands Aquifer System}

The Coastal lowlands aquifer system extends from the Rio Grande River in Texas across southern and central Louisiana, southern Mississippi, southern Alabama, and the western part of the Florida panhandle (Renken, 1998) and encompasses about 140,000 $\mathrm{mi}^{2}$ (Grubb, 1998). The aquifer system consists of unconsolidated to poorly consolidated layers of sand, silt, and clay that range in age from Oligocene to Holocene and thicken seaward.

Withdrawals from the Coastal lowlands aquifer system were 2,370 Mgal/d (2,660 taf/yr), which constituted 3 percent of withdrawals from all of the principal aquifers. The Coastal lowlands aquifer system provided the second largest self-supplied industrial withdrawals among the principal aquifers. Public-supply withdrawals were $1,010 \mathrm{Mgal} / \mathrm{d}$, or 43 percent of the total withdrawals; irrigation withdrawals were $933 \mathrm{Mgal} / \mathrm{d}$, or 39 percent; and self-supplied industrial withdrawals were $425 \mathrm{Mgal} / \mathrm{d}$, or 18 percent. Most of the withdrawals from this aquifer system were in Louisiana (43 percent) and Texas (41 percent) (table 2).

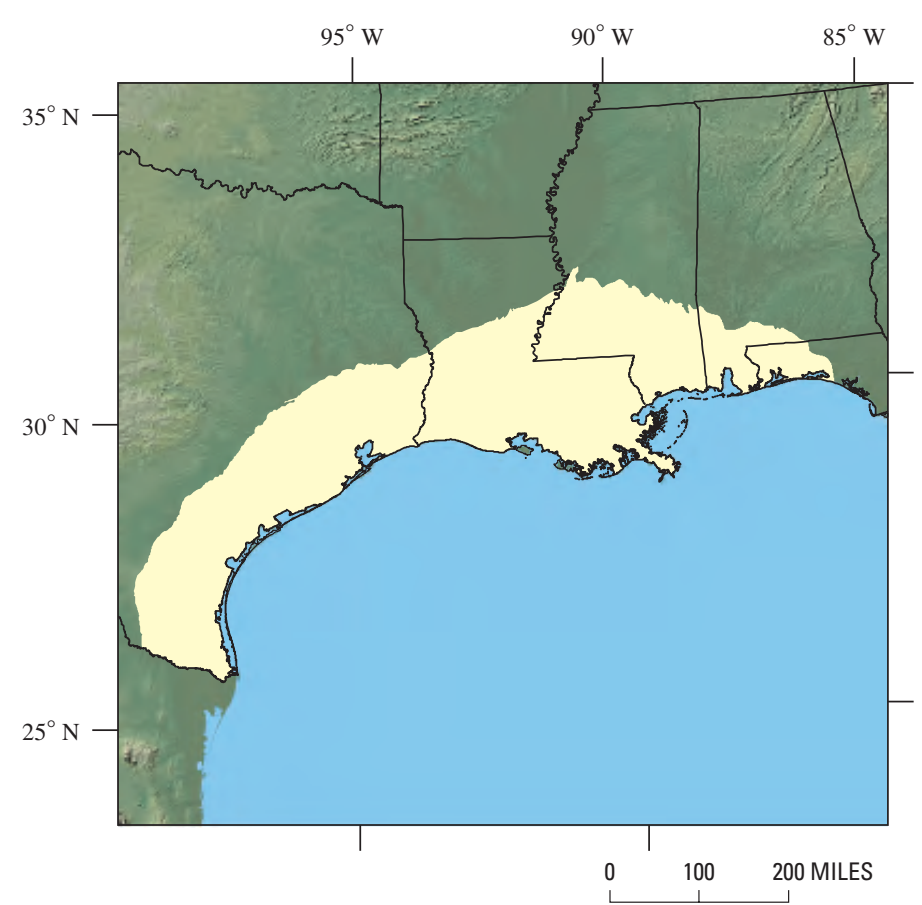

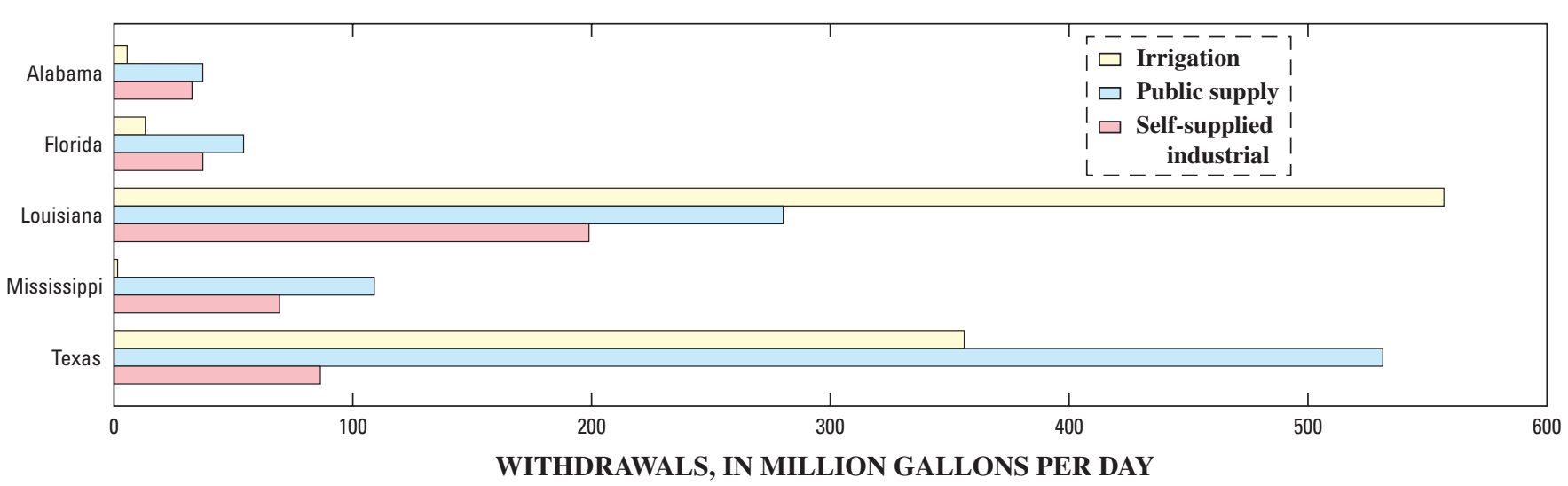

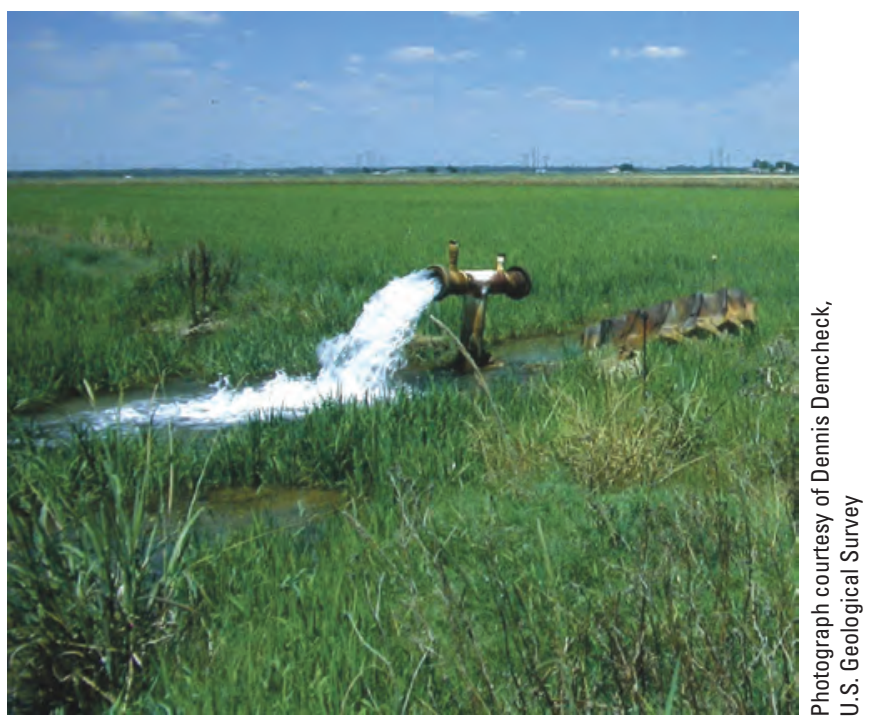

Pumpage from Coastal lowlands aquifer system to irrigate rice

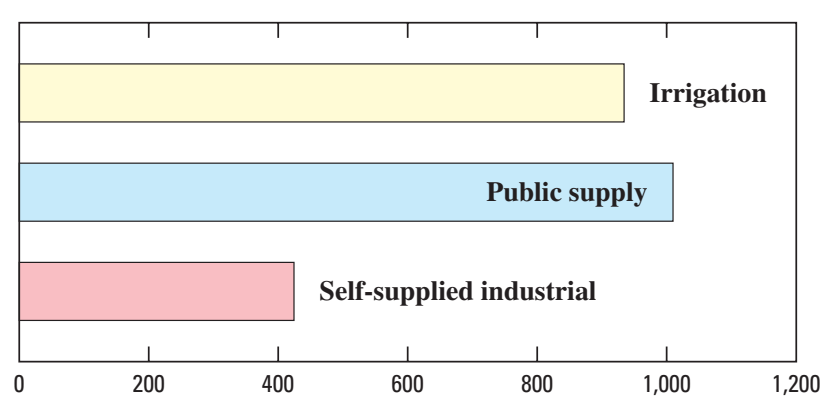

WITHDRAWALS, IN MILLION GALLONS PER DAY 


\section{REFERENCES CITED}

Grannemann, N.G., Hunt, R.J., Nicholas, J.R., Reilly, T.E., and Winter, T.C., 2000, The importance of ground water in the Great Lakes Region: U.S. Geological Survey WaterResources Investigations Report 00-4008, 14 p.

Grubb, H.F, 1998, Summary of hydrology of the regional aquifer systems, Gulf Coastal Plain, south-central United States: U.S. Geological Survey Professional Paper 1416-A, 61 p.

Hutson, S.S., Barber, N.L., Kenny, J.F., Linsey, K.S., Lumia, D.S., and Maupin, M.A., 2004, Estimated use of water in the United States in 2000: U.S. Geological Survey Circular 1268, 46 p., accessed October 5, 2004, at http://water.usgs.gov/pubs/circ/2004/circ1268

Kenny, J.F., 2004, Guidelines for preparation of State wateruse estimates for 2000: U.S. Geological Survey Techniques and Methods 4-4A, 49 p., accessed January 4, 2005, at http://pubs.water.usgs.gov/tm4a4/

McGuire, V.L., Johnson, M.R., Schieffer, R.L., Stanton, J.S., Sebree, S.K., and Verstraeten, I.M., 2003, Water in storage and approaches to ground-water management, High Plains aquifer, 2000: U.S. Geological Survey Circular 1243, 51 p., accessed March 14, 2005, at http://water.usgs.gov/pubs/circ/2003/circ1243

Miller, J.A., 1990, Ground water atlas of the United States Segment 6, Alabama, Florida, Georgia, and South Carolina: U.S. Geological Survey Hydrologic Investigations Atlas 730-G, 28 p.

Miller, J.A., ed., 2000, Ground-water atlas of the United States: U.S. Geological Survey, 404 p.

National Oceanic and Atmospheric Administration, 2001, Climate of 2000 - annual review, U.S. summary, January 12, 2001: National Climatic Data Center, accessed August 4, 2003, at http://www.ncdc.noaa.gov/oa/ climate/research/2000/ann/us_summary.html
Olcott, P.G., 1995, Ground-water atlas of the United StatesSegment 12, Connecticut, Maine, Massachusetts, New Hampshire, New York, Rhode Island, and Vermont: U.S. Geological Survey Hydrologic Investigations Atlas 730-M, 28 p.

Planert, Michael, and Williams, J.S., 1995, Ground-water atlas of the United States - Segment 1, California, Nevada: U.S. Geological Survey Hydrologic Investigations Atlas 730-B, 28 p.

Renken, R.A., 1998, Ground-water atlas of the United States - Segment 5, Arkansas, Louisiana, Mississippi: U.S. Geological Survey Hydrologic Investigations Atlas 730-F, 28 p.

U.S. Geological Survey, 1999, Ground Water: U.S. Geological Survey General Interest Publication, accessed October 5, 2004, at http://capp.water.usgs.gov/GIP/gw_gip/index.html

2003, Principal aquifers, in National Atlas of the United States of America, 1 sheet, accessed October 5, 2004, at http://nationalatlas.gov/mld/aquifrp.html

Whitehead, R.L., 1994, Ground water atlas of the United States - Segment 7, Idaho, Oregon, Washington: U.S. Geological Survey Hydrologic Investigations Atlas 730-H, 30 p.

Williamson, A.K., Prudic, D.E., and Swain, L.A., 1989, Ground-water flow in the Central Valley, California: U.S. Geological Survey Professional Paper 1401-D, 127 p. 
[This page intentionally left blank] 
Table 2 
[This page intentionally left blank] 
Table 2. Total ground-water withdrawals, by aquifer and State, for irrigation, public-supply, and self-supplied industrial water uses, 2000

[Total values have been rounded; No., aquifer number as shown in figure 1 explanation; bold denotes totals collected for that particular aquifer, *, not shown in figure 1 explanation.]

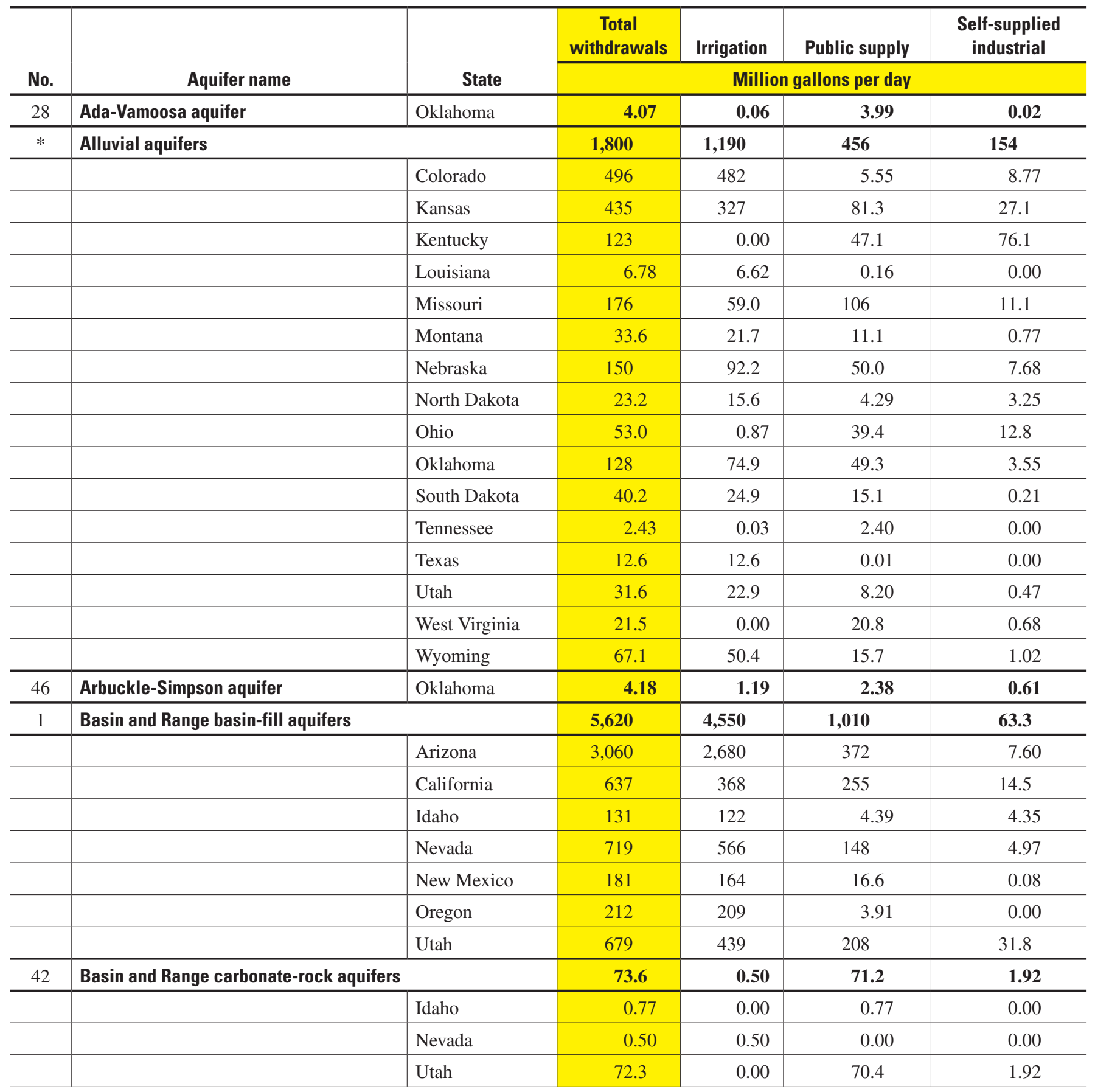


Table 2. Total ground-water withdrawals, by aquifer and State, for irrigation, public-supply, and self-supplied industrial water uses, 2000 - Continued

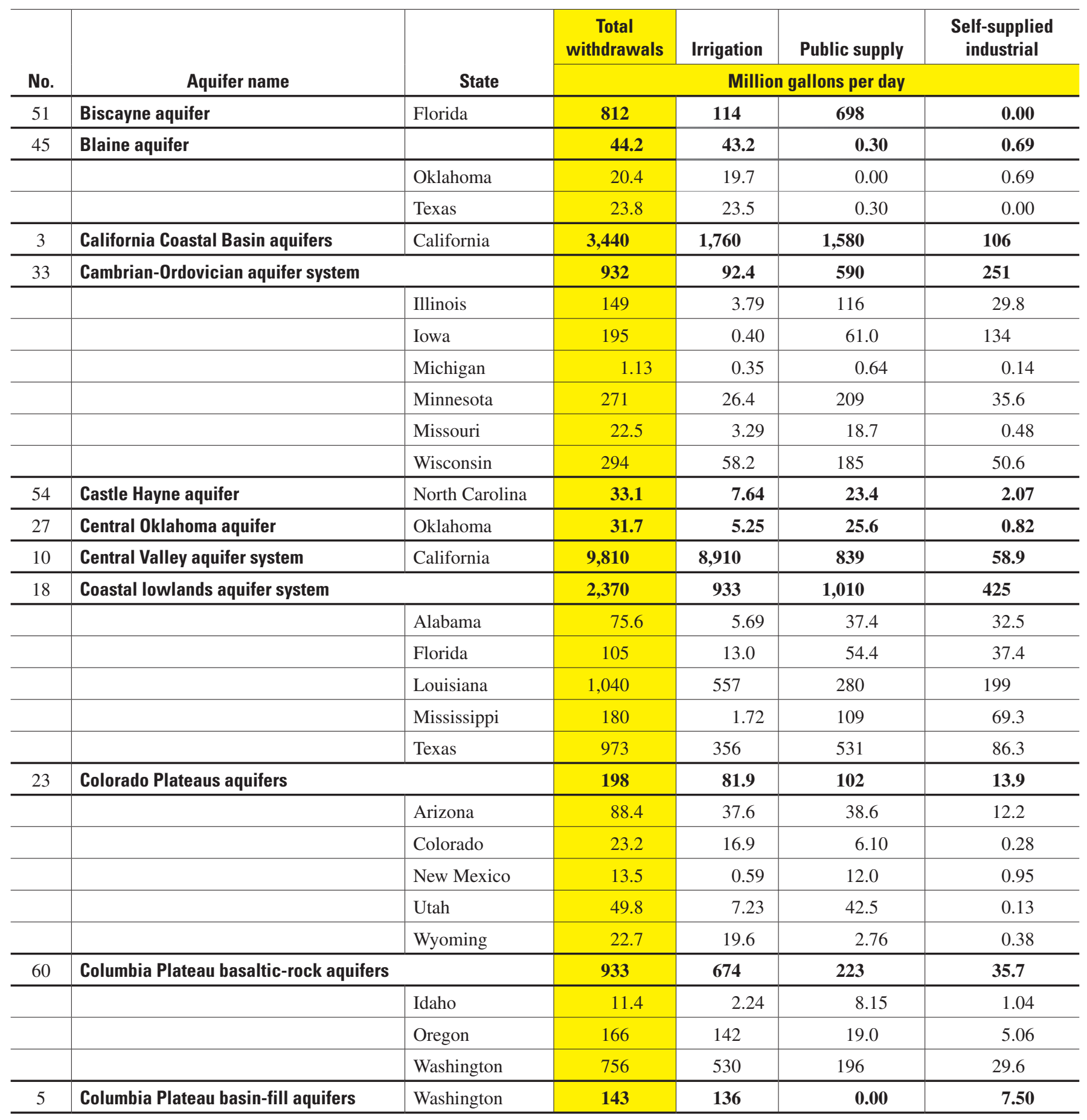


Table 2. Total ground-water withdrawals, by aquifer and State, for irrigation, public-supply, and self-supplied industrial water uses, 2000 - Continued

\begin{tabular}{|c|c|c|c|c|c|c|}
\hline \multirow[b]{2}{*}{ No. } & \multirow[b]{2}{*}{ Aquifer name } & \multirow[b]{2}{*}{ State } & $\begin{array}{c}\text { Total } \\
\text { withdrawals }\end{array}$ & Irrigation & Public supply & $\begin{array}{c}\text { Self-supplied } \\
\text { industrial }\end{array}$ \\
\hline & & & \multicolumn{4}{|c|}{ Million gallons per day } \\
\hline 24 & Denver Basin aquifer system & Colorado & 36.3 & 11.9 & 16.9 & 7.44 \\
\hline \multirow[t]{8}{*}{29} & \multicolumn{2}{|l|}{ Early Mesozoic basin aquifers } & 131 & 6.42 & 108 & 17.1 \\
\hline & & Connecticut & 17.2 & 3.31 & 13.4 & 0.44 \\
\hline & & Maryland & 1.29 & 0.06 & 1.21 & 0.02 \\
\hline & & Massachusetts & 0.02 & 0.00 & 0.02 & 0.00 \\
\hline & & North Carolina & 1.31 & 1.09 & 0.22 & 0.00 \\
\hline & & New Jersey & 67.4 & 1.62 & 55.6 & 10.2 \\
\hline & & Pennsylvania & 41.9 & 0.25 & 35.6 & 6.07 \\
\hline & & Virginia & 2.07 & 0.09 & 1.59 & 0.39 \\
\hline \multirow[t]{4}{*}{38} & \multicolumn{2}{|l|}{ Edwards-Trinity aquifer system } & 740 & 282 & 411 & 47.2 \\
\hline & & Arkansas & 7.54 & 0.00 & 7.31 & 0.23 \\
\hline & & Oklahoma & 4.26 & 1.96 & 2.12 & 0.18 \\
\hline & & Texas & 729 & 280 & 402 & 46.8 \\
\hline \multirow[t]{5}{*}{50} & \multicolumn{2}{|l|}{ Floridan aquifer system } & 3,640 & 1,930 & 1,330 & 385 \\
\hline & & Alabama & 5.91 & 1.46 & 2.33 & 2.15 \\
\hline & & Florida & 2,790 & 1,460 & 1,160 & 173 \\
\hline & & Georgia & 782 & 436 & 142 & 205 \\
\hline & & South Carolina & 57.6 & 28.5 & 24.5 & 4.61 \\
\hline \multirow[t]{15}{*}{ Gray } & \multicolumn{2}{|l|}{ Glacial sand and gravel aquifers } & 3,560 & 1,020 & 1,950 & 583 \\
\hline & & Connecticut & 14.3 & 2.62 & 11.3 & 0.38 \\
\hline & & Illinois & 413 & 140 & 181 & 91.9 \\
\hline & & Indiana & 455 & 50.6 & 309 & 94.9 \\
\hline & & Iowa & 265 & 18.0 & 171 & 76.6 \\
\hline & & Kansas & 5.09 & 0.33 & 4.69 & 0.07 \\
\hline & & Maine & 19.8 & 0.31 & 14.6 & 4.92 \\
\hline & & Massachusetts & 226 & 19.7 & 196 & 10.7 \\
\hline & & Michigan & 338 & 106 & 157 & 75.7 \\
\hline & & Minnesota & 282 & 160 & 104 & 18.1 \\
\hline & & Montana & 33.9 & 28.4 & 5.34 & 0.11 \\
\hline & & Nebraska & 202 & 200 & 2.04 & 0.01 \\
\hline & & New Hampshire & 30.4 & 0.37 & 25.3 & 4.72 \\
\hline & & New Jersey & 84.4 & 0.47 & 80.5 & 3.37 \\
\hline & & New York & 263 & 16.4 & 175 & 71.6 \\
\hline
\end{tabular}


Table 2. Total ground-water withdrawals, by aquifer and State, for irrigation, public-supply, and self-supplied industrial water uses, 2000 - Continued

\begin{tabular}{|c|c|c|c|c|c|c|}
\hline \multirow[b]{2}{*}{ No. } & \multirow[b]{2}{*}{ Aquifer name } & \multirow[b]{2}{*}{ State } & $\begin{array}{c}\text { Total } \\
\text { withdrawals }\end{array}$ & Irrigation & Public supply & $\begin{array}{l}\text { Self-supplied } \\
\text { industrial }\end{array}$ \\
\hline & & & \multicolumn{4}{|c|}{ Million gallons per day } \\
\hline \multirow{4}{*}{ Gray } & & Ohio & 421 & 8.20 & 312 & 101 \\
\hline & & South Dakota & 118 & 90.9 & 26.4 & 0.17 \\
\hline & & Vermont & 16.6 & 0.26 & 14.8 & 1.55 \\
\hline & & Wisconsin & 273 & 126 & 125 & 22.4 \\
\hline \multirow[t]{6}{*}{11} & \multicolumn{2}{|l|}{ High Plains aquifer } & 17,500 & 17,000 & 389 & 99.2 \\
\hline & & New Mexico & 522 & 498 & 23.1 & 1.06 \\
\hline & & Oklahoma & 414 & 400 & 13.5 & 0.12 \\
\hline & & South Dakota & 19.2 & 16.7 & 2.46 & 0.00 \\
\hline & & Texas & 5,200 & 5,080 & 75.2 & 52.8 \\
\hline & & Wyoming & 293 & 281 & 9.89 & 1.94 \\
\hline$*$ & Intermediate aquifer system (Florida) & Florida & 354 & 292 & 61.2 & 0.74 \\
\hline 34 & Jacobsville aquifer & Michigan & 3.01 & 0.06 & 2.81 & 0.14 \\
\hline 56 & Kingshill aquifer (Virgin Islands) & Virgin Islands & 0.74 & 0.00 & 0.52 & 0.22 \\
\hline \multirow[t]{8}{*}{20} & \multicolumn{2}{|l|}{ Mississippi embayment aquifer system } & 946 & 195 & 576 & 175 \\
\hline & & Alabama & 9.83 & 0.31 & 8.93 & 0.59 \\
\hline & & Arkansas & 322 & 184 & 77.2 & 61.0 \\
\hline & & Kentucky & 21.1 & 0.00 & 10.8 & 10.3 \\
\hline & & Louisiana & 102 & 6.26 & 64.9 & 30.9 \\
\hline & & Mississippi & 172 & 0.71 & 146 & 25.2 \\
\hline & & Missouri & 10.3 & 0.00 & 10.2 & 0.09 \\
\hline & & Tennessee & 309 & 3.49 & 258 & 46.8 \\
\hline
\end{tabular}


Table 2. Total ground-water withdrawals, by aquifer and State, for irrigation, public-supply, and self-supplied industrial water uses, 2000 - Continued

\begin{tabular}{|c|c|c|c|c|c|c|}
\hline \multirow[b]{2}{*}{ No. } & \multirow[b]{2}{*}{ Aquifer name } & \multirow[b]{2}{*}{ State } & $\begin{array}{c}\text { Total } \\
\text { withdrawals }\end{array}$ & Irrigation & Public supply & $\begin{array}{l}\text { Self-supplied } \\
\text { industrial }\end{array}$ \\
\hline & & & \multicolumn{4}{|c|}{ Million gallons per day } \\
\hline \multirow[t]{6}{*}{13} & \multicolumn{2}{|l|}{ Mississippi River Valley alluvial aquifer } & 9,290 & 9,150 & 69.8 & 70.4 \\
\hline & & Arkansas & 6,370 & 6,320 & 40.5 & 5.74 \\
\hline & & Louisiana & 282 & 221 & 7.27 & 54.3 \\
\hline & & Mississippi & 1,320 & 1,310 & 10.4 & 6.69 \\
\hline & & Missouri & 1,310 & 1,300 & 11.7 & 3.68 \\
\hline & & Tennessee & 1.34 & 1.34 & 0.00 & 0.00 \\
\hline \multirow[t]{13}{*}{40} & \multicolumn{2}{|l|}{ Mississippian aquifers } & 286 & 6.31 & 211 & 67.9 \\
\hline & & Alabama & 42.3 & 1.64 & 34.6 & 6.12 \\
\hline & & Illinois & 4.38 & 0.00 & 1.20 & 3.18 \\
\hline & & Indiana & 2.88 & 0.37 & 1.16 & 1.35 \\
\hline & & Iowa & 7.01 & 0.47 & 4.89 & 1.65 \\
\hline & & Kentucky & 17.4 & 0.00 & 9.06 & 8.30 \\
\hline & & Maryland & 1.08 & 0.01 & 1.00 & 0.07 \\
\hline & & Missouri & 22.5 & 3.29 & 18.7 & 0.48 \\
\hline & & Ohio & 158 & 0.00 & 119 & 38.6 \\
\hline & & Pennsylvania & 5.36 & 0.06 & 3.74 & 1.56 \\
\hline & & Tennessee & 24.1 & 0.47 & 17.3 & 6.35 \\
\hline & & Virginia & 0.07 & 0.00 & 0.02 & 0.05 \\
\hline & & West Virginia & 0.88 & 0.00 & 0.69 & 0.19 \\
\hline \multirow[t]{8}{*}{$*$} & \multicolumn{2}{|l|}{ New England crystalline-rock aquifers } & 96.3 & 11.1 & 73.6 & 11.6 \\
\hline & & Connecticut & 52.1 & 10.4 & 38.6 & 3.09 \\
\hline & & Maine & 19.8 & 0.31 & 14.6 & 4.92 \\
\hline & & Massachusetts & 0.41 & 0.00 & 0.41 & 0.00 \\
\hline & & New Hampshire & 10.0 & 0.11 & 7.68 & 2.22 \\
\hline & & New York & 8.15 & 0.17 & 7.40 & 0.58 \\
\hline & & Rhode Island & 0.60 & 0.02 & 0.27 & 0.31 \\
\hline & & Vermont & 5.25 & 0.09 & 4.67 & 0.49 \\
\hline \multirow[t]{5}{*}{52} & \multicolumn{2}{|c|}{ New York and New England carbonate-rock aquifers } & 46.4 & 1.98 & 35.8 & 8.64 \\
\hline & & Connecticut & 3.54 & 0.63 & 2.70 & 0.21 \\
\hline & & Maine & 0.48 & 0.01 & 0.42 & 0.05 \\
\hline & & New York & 40.3 & 1.34 & 30.6 & 8.29 \\
\hline & & Pennsylvania & 2.13 & 0.00 & 2.04 & 0.09 \\
\hline
\end{tabular}


Table 2. Total ground-water withdrawals, by aquifer and State, for irrigation, public-supply, and self-supplied industrial water uses, 2000 - Continued

\begin{tabular}{|c|c|c|c|c|c|c|}
\hline \multirow[b]{2}{*}{ No. } & \multirow[b]{2}{*}{ Aquifer name } & \multirow[b]{2}{*}{ State } & $\begin{array}{c}\text { Total } \\
\text { withdrawals }\end{array}$ & Irrigation & Public supply & $\begin{array}{l}\text { Self-supplied } \\
\text { industrial }\end{array}$ \\
\hline & & & \multicolumn{4}{|c|}{ Million gallons per day } \\
\hline 55 & $\begin{array}{l}\text { North Coast Limestone aquifer system } \\
\text { (Puerto Rico) }\end{array}$ & Puerto Rico & 58.9 & 5.71 & 46.8 & 6.41 \\
\hline \multirow{5}{*}{22} & & Delaware & 40.4 & 3.00 & 29.5 & 7.89 \\
\hline & & Maryland & 85.4 & 9.72 & 66.3 & 9.34 \\
\hline & & New Jersey & 317 & 20.3 & 248 & 48.3 \\
\hline & & New York & 359 & 4.28 & 326 & 28.3 \\
\hline & & North Carolina & 142 & 31.4 & 91.8 & 18.4 \\
\hline \multirow[t]{5}{*}{$*$} & \multicolumn{2}{|l|}{ Northern Great Plains aquifer system } & 101 & 66.6 & 33.0 & 1.62 \\
\hline & & Montana & 11.0 & 4.55 & 5.84 & 0.58 \\
\hline & & North Dakota & 5.35 & 1.59 & 3.42 & 0.34 \\
\hline & & South Dakota & 6.28 & 0.95 & 5.26 & 0.07 \\
\hline & & Wyoming & 78.6 & 59.5 & 18.5 & 0.63 \\
\hline \multirow[t]{3}{*}{9} & \multicolumn{2}{|l|}{$\begin{array}{l}\text { Northern Rocky Mountains Intermontane } \\
\text { Basins aquifer system }\end{array}$} & 378 & 264 & 78.4 & 35.1 \\
\hline & & Idaho & 240 & 210 & 30.6 & 0.30 \\
\hline & & Montana & 92.7 & 28.3 & 33.9 & 30.5 \\
\hline \multirow{10}{*}{ Other } & & Alaska & 1.66 & 0.00 & 1.47 & 0.19 \\
\hline & & Arizona & 88.2 & 29.9 & 58.3 & 0.00 \\
\hline & & California & 181 & 89.1 & 91.4 & 0.16 \\
\hline & & Colorado & 114 & 89.4 & 18.4 & 6.44 \\
\hline & & Delaware & 2.44 & 0.14 & 2.30 & 0.00 \\
\hline & & Illinois & 10.9 & 0.00 & 6.70 & 4.24 \\
\hline & & Indiana & 0.10 & 0.00 & 0.08 & 0.02 \\
\hline & & Iowa & 0.57 & 0.06 & 0.51 & 0.00 \\
\hline & & Kansas & 89.0 & 83.4 & 5.10 & 0.48 \\
\hline & & Kentucky & 1.24 & 1.24 & 0.00 & 0.00 \\
\hline
\end{tabular}


Table 2. Total ground-water withdrawals, by aquifer and State, for irrigation, public-supply, and self-supplied industrial water uses, 2000 - Continued

\begin{tabular}{|c|c|c|c|c|c|c|}
\hline \multirow[b]{2}{*}{ No. } & \multirow[b]{2}{*}{ Aquifer name } & \multirow[b]{2}{*}{ State } & $\begin{array}{c}\text { Total } \\
\text { withdrawals }\end{array}$ & Irrigation & Public supply & $\begin{array}{l}\text { Self-supplied } \\
\text { industrial }\end{array}$ \\
\hline & & & \multicolumn{4}{|c|}{ Million gallons per day } \\
\hline \multirow[t]{19}{*}{ Other } & Other-Continued & Michigan & 2.02 & 0.02 & 1.59 & 0.41 \\
\hline & & Minnesota & 4.70 & 0.00 & 4.70 & 0.00 \\
\hline & & Mississippi & 6.33 & 0.00 & 6.33 & 0.00 \\
\hline & & Nebraska & 15.5 & 4.12 & 10.3 & 1.08 \\
\hline & & Nevada & 3.61 & 0.00 & 3.29 & 0.32 \\
\hline & & New Mexico & 83.9 & 66.5 & 17.0 & 0.38 \\
\hline & & New York & 25.2 & 0.25 & 9.20 & 15.8 \\
\hline & & North Dakota & 7.06 & 2.34 & 4.28 & 0.44 \\
\hline & & Ohio & 5.81 & 0.06 & 4.35 & 1.40 \\
\hline & & Oklahoma & 19.3 & 13.3 & 5.83 & 0.17 \\
\hline & & Pennsylvania & 109 & 0.10 & 81.0 & 28.2 \\
\hline & & Puerto Rico & 33.2 & 14.4 & 16.2 & 2.60 \\
\hline & & South Dakota & 1.90 & 0.00 & 0.51 & 1.39 \\
\hline & & Tennessee & 0.05 & 0.04 & 0.00 & 0.01 \\
\hline & & Texas & 310 & 283 & 24.1 & 2.80 \\
\hline & & Utah & 31.7 & 0.00 & 31.7 & 0.01 \\
\hline & & Wisconsin & 7.81 & 3.65 & 3.31 & 0.85 \\
\hline & & West Virginia & 1.72 & 0.00 & 1.58 & 0.14 \\
\hline & & Wyoming & 3.30 & 2.42 & 0.63 & 0.25 \\
\hline \multirow[t]{5}{*}{44} & \multicolumn{2}{|l|}{ Ozark Plateaus aquifer system } & 165 & 20.5 & 131 & 14.0 \\
\hline & & Arkansas & 8.44 & 1.23 & 7.16 & 0.05 \\
\hline & & Kansas & 7.12 & 0.06 & 6.77 & 0.29 \\
\hline & & Missouri & 145 & 19.2 & 113 & 13.4 \\
\hline & & Oklahoma & 4.30 & 0.00 & 4.02 & 0.28 \\
\hline \multirow[t]{5}{*}{4} & \multicolumn{2}{|l|}{ Pacific Northwest basin-fill aquifers } & 865 & 784 & 71.8 & 9.28 \\
\hline & & California & 367 & 333 & 30.6 & 3.01 \\
\hline & & Idaho & 434 & 406 & 26.1 & 2.26 \\
\hline & & Oregon & 51.8 & 41.4 & 7.90 & 2.52 \\
\hline & & Washington & 12.1 & 3.42 & 7.23 & 1.49 \\
\hline \multirow[t]{6}{*}{58} & \multicolumn{2}{|l|}{ Pacific Northwest basaltic-rock aquifers } & 475 & 422 & 48.8 & 4.21 \\
\hline & & California & 193 & 188 & 4.40 & 0.01 \\
\hline & & Idaho & 108 & 105 & 0.00 & 3.29 \\
\hline & & Oregon & 162 & 129 & 31.8 & 0.91 \\
\hline & & Utah & 3.31 & 0.00 & 3.31 & 0.00 \\
\hline & & Washington & 9.30 & 0.00 & 9.30 & 0.00 \\
\hline
\end{tabular}


Table 2. Total ground-water withdrawals, by aquifer and State, for irrigation, public-supply, and self-supplied industrial water uses, 2000 - Continued

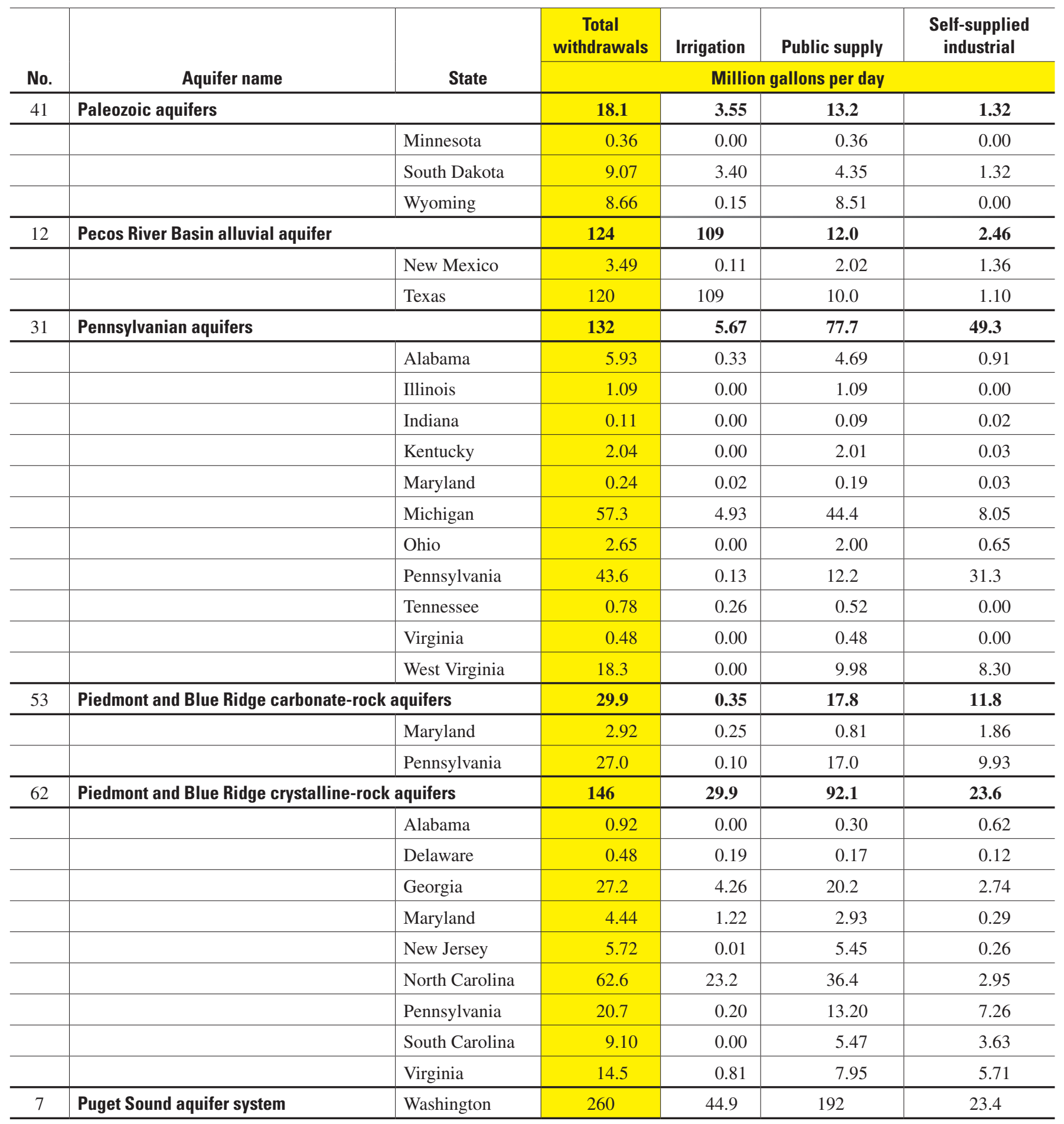


Table 2. Total ground-water withdrawals, by aquifer and State, for irrigation, public-supply, and self-supplied industrial water uses, 2000 - Continued

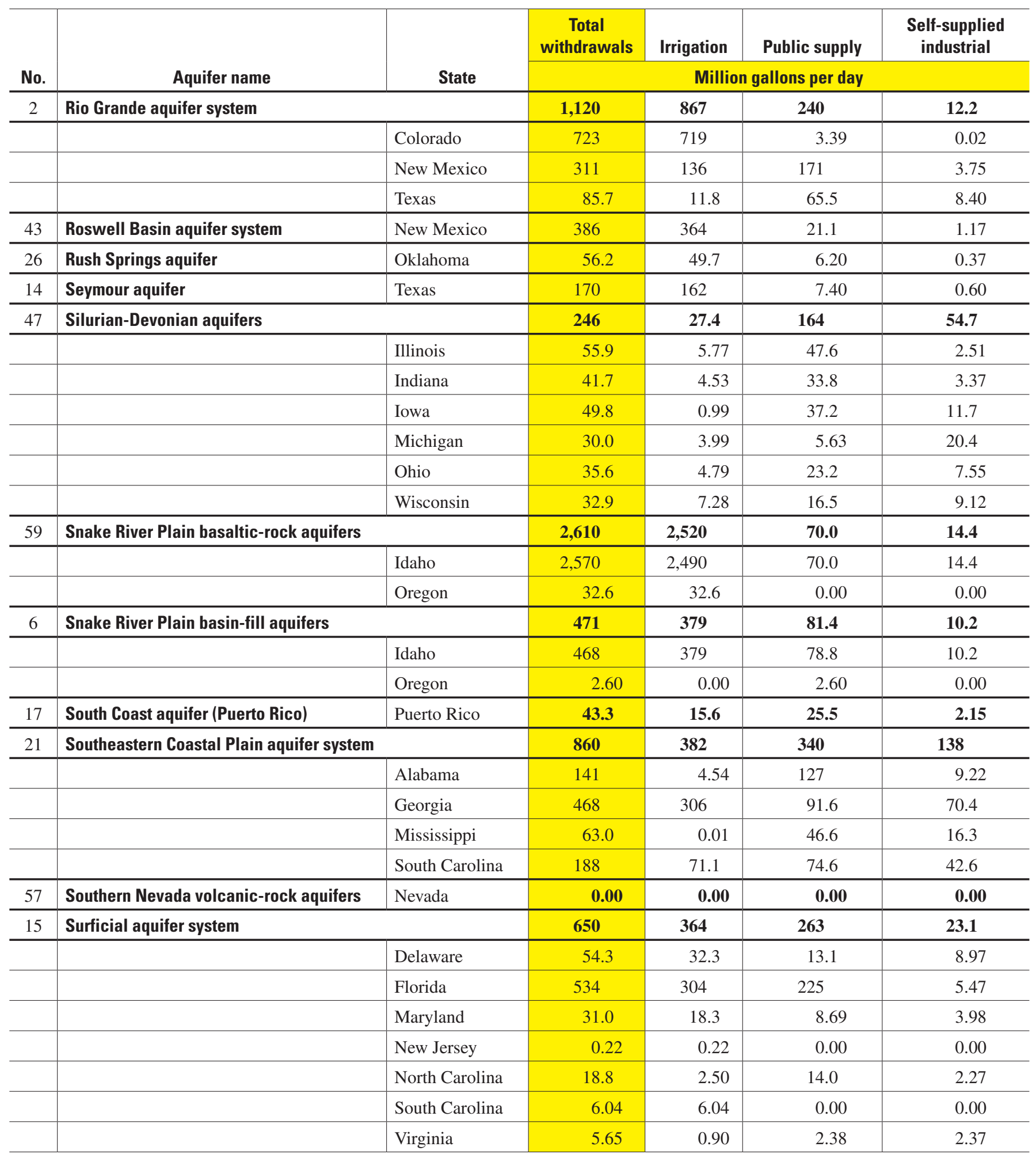


Table 2. Total ground-water withdrawals, by aquifer and State, for irrigation, public-supply, and self-supplied industrial water uses, 2000 - Continued

\begin{tabular}{|c|c|c|c|c|c|c|}
\hline \multirow[b]{2}{*}{ No. } & \multirow[b]{2}{*}{ Aquifer name } & \multirow[b]{2}{*}{ State } & $\begin{array}{c}\text { Total } \\
\text { withdrawals }\end{array}$ & Irrigation & Public supply & $\begin{array}{c}\text { Self-supplied } \\
\text { industrial }\end{array}$ \\
\hline & & & \multicolumn{4}{|c|}{ Million gallons per day } \\
\hline 16 & Unconsolidated-deposit aquifers (Alaska) & Alaska & 33.0 & 0.99 & 27.8 & 4.13 \\
\hline 49 & Upper carbonate aquifer & Minnesota & 9.55 & 0.35 & 7.52 & 1.68 \\
\hline \multirow[t]{4}{*}{39} & \multicolumn{2}{|l|}{ Valley and Ridge aquifers } & 95.0 & 0.61 & 48.9 & 45.5 \\
\hline & & Maryland & 1.89 & 0.06 & 1.79 & 0.04 \\
\hline & & New Jersey & 1.13 & 0.05 & 0.92 & 0.16 \\
\hline & & Pennsylvania & 45.6 & 0.37 & 18.5 & 26.8 \\
\hline \multirow[t]{8}{*}{39} & \multicolumn{2}{|l|}{ Valley and Ridge carbonate-rock aquifers } & 267 & 5.65 & 177 & 83.9 \\
\hline & & Alabama & 71.2 & 0.49 & 66.5 & 3.95 \\
\hline & & Georgia & 39.7 & 3.35 & 24.4 & 11.9 \\
\hline & & Maryland & 2.08 & 0.17 & 1.64 & 0.27 \\
\hline & & New Jersey & 12.8 & 0.12 & 9.66 & 3.07 \\
\hline & & Pennsylvania & 69.9 & 0.16 & 25.7 & 44.0 \\
\hline & & Tennessee & 33.0 & 1.17 & 28.7 & 3.19 \\
\hline & & Virginia & 30.8 & 0.18 & 13.3 & 17.4 \\
\hline \multicolumn{3}{|c|}{ TOTAL } & 76,500 & 56,900 & 16,000 & $\mathbf{3 , 5 7 0}$ \\
\hline
\end{tabular}


